\title{
Identification of high-use internesting habitats for eastern Pacific leatherback turtles: role of the environment and implications for conservation
}

\author{
George L. Shillinger ${ }^{1, *}$, Alan M. Swithenbank ${ }^{1}$, Steven J. Bograd ${ }^{2}$, Helen Bailey ${ }^{2}$, \\ Michael R. Castelton" ${ }^{1}$, Bryan P. Wallace ${ }^{3}$, James R. Spotila ${ }^{4}$, Frank V. Paladino ${ }^{5}$, \\ Rotney Piedra ${ }^{6}$, Barbara A. Block ${ }^{1}$ \\ ${ }^{1}$ Hopkins Marine Station, Stanford University, Pacific Grove, California 93950, USA \\ ${ }^{2}$ NOAA/NMFS/SWFSC/Environmental Research Division, Pacific Grove, California 93950, USA \\ ${ }^{3}$ Center for Applied Biodiversity Science, Conservation International, Arlington, Virginia 22202, USA \\ ${ }^{4}$ Department of Bioscience and Biotechnology, Drexel University, Philadelphia, Pennsylvania 19104, USA \\ ${ }^{5}$ Department of Biology, Indiana University-Purdue University, Fort Wayne, Indiana 46805, USA \\ ${ }^{6}$ Parque Nacional Marino Las Baulas, Ministerio de Ambiente y Energía, Apartado 10104-1000, San José, Costa Rica
}

\begin{abstract}
The numbers of leatherback turtles Dermochelys coriacea in the eastern Pacific Ocean have declined by up to $90 \%$ in the past 2 decades. Initially, egg harvesting was determined to be the largest causative factor, but now that this has been eliminated, high estimated adult mortality from fisheries bycatch poses the single greatest threat to this population. During the nesting season, adult female leatherback turtles nest multiple times and occupy coastal marine habitats near their nesting beaches. In this study, we characterize the interannual variability of high-use internesting habitats used by 44 (out of 46 total) female leatherback turtles that were satellite-tagged at Playa Grande, Costa Rica, from 2004 to 2007. A total of 1135 d of internesting movements were recorded across 3 tracking years. The core $25 \%$ utilization distribution (UD) remained predominantly centered within the marine protected area, Parque Nacional Marino Las Baulas (PNMB). The turtles generally dispersed in a northward or southward direction over the shallow continental shelf framing Costa Rica's Nicoya Peninsula. However, there was considerable interannual variation in the shape and area of the larger UD polygons, which was driven by variability in the thermal environment. The maximum swimming speeds and distance traveled from the nesting beach occurred during 2007. Significantly deeper and longer dive durations to cooler temperatures also occurred in this year, which may have been in response to the warming trend from the south driven by the strong Costa Rica Coastal Current. Our findings, therefore, validate the importance of PNMB as a critical habitat for internesting leatherback turtles, but also suggest that a latitudinal expansion of the park is warranted.
\end{abstract}

KEY WORDS: Conservation $\cdot$ Costa Rica $\cdot$ Dermochelys coriacea $\cdot$ Diving behavior $\cdot$ Marine Spatial Planning $\cdot$ Marine turtles $\cdot$ Satellite tracking

Resale or republication not permitted without written consent of the publisher

\section{INTRODUCTION}

Eastern Pacific (EP) leatherback turtles Dermochelys coriacea have declined by up to $90 \%$ during the past 2 decades and are currently classified as Critically Endangered (Spotila et al. 2000). These declines have been driven by many factors operating synergistically, including environmental variation in foraging areas, habitat loss, poaching and fisheries bycatch (Spotila et al. 2000, Santidrián-Tomillo et al. 2008, Wallace \& Saba 2009). Life history theory implies that populations of these leatherback turtles, because they are long-lived and slow to mature, are particularly vulnerable to the effects of adult mortality (Stearns 1992). A population modeling study (Santidrián-Tomillo et al. 2008) determined that egg harvesting was the largest causative 
factor of the leatherback turtle population decline at Parque Nacional Marino Las Baulas (PNMB), Costa Rica, and substantiated the importance of ongoing nesting-beach conservation efforts to enhance turtle recruitment. However, because poaching has been eliminated by the existence of beach patrols and strong enforcement by the Costa Rican Ministerio del Ambiente, Energia y Telecomunicaciones (MINAET), estimated high adult mortality ( $22 \%)$, presumably from bycatch, presents the single greatest threat to the EP population (Santidrián-Tomillo et al. 2008). An integrated approach addressing threats to early and late stages is therefore necessary for effective leatherback turtle conservation (Congdon et al. 1993, Heppell et al. 1996).

Leatherback turtles nesting within PNMB along the Pacific coast of Costa Rica show strong nest site fidelity to 3 specific beaches (Playa Grande, Playa Langosta and Playa Flamingo; $10^{\circ} 20^{\prime} \mathrm{N}, 85^{\circ} 51^{\prime} \mathrm{W}$; Fig. 1) (Reina et al. 2002, Nordmoe et al. 2004, Santidrián-Tomillo et al. 2007). These 3 beaches support the highest density nesting colony of leatherback turtles in the eastern Pacific Ocean (Spotila et al. 2000). Leatherback turtles at PNMB nest multiple times within a single season at approximately 8 to $10 \mathrm{~d}$ intervals (Steyermark et al. 1996); these intervals are also referred to as internesting periods.

Although the postnesting movements of adult female leatherback turtles within the tropical eastern Pacific have been well described (Morreale et al. 1996, Shillinger et al. 2008), little is known about the fine-scale use of critical internesting habitats, an area essential to the conservation of this population, during the reproduc-

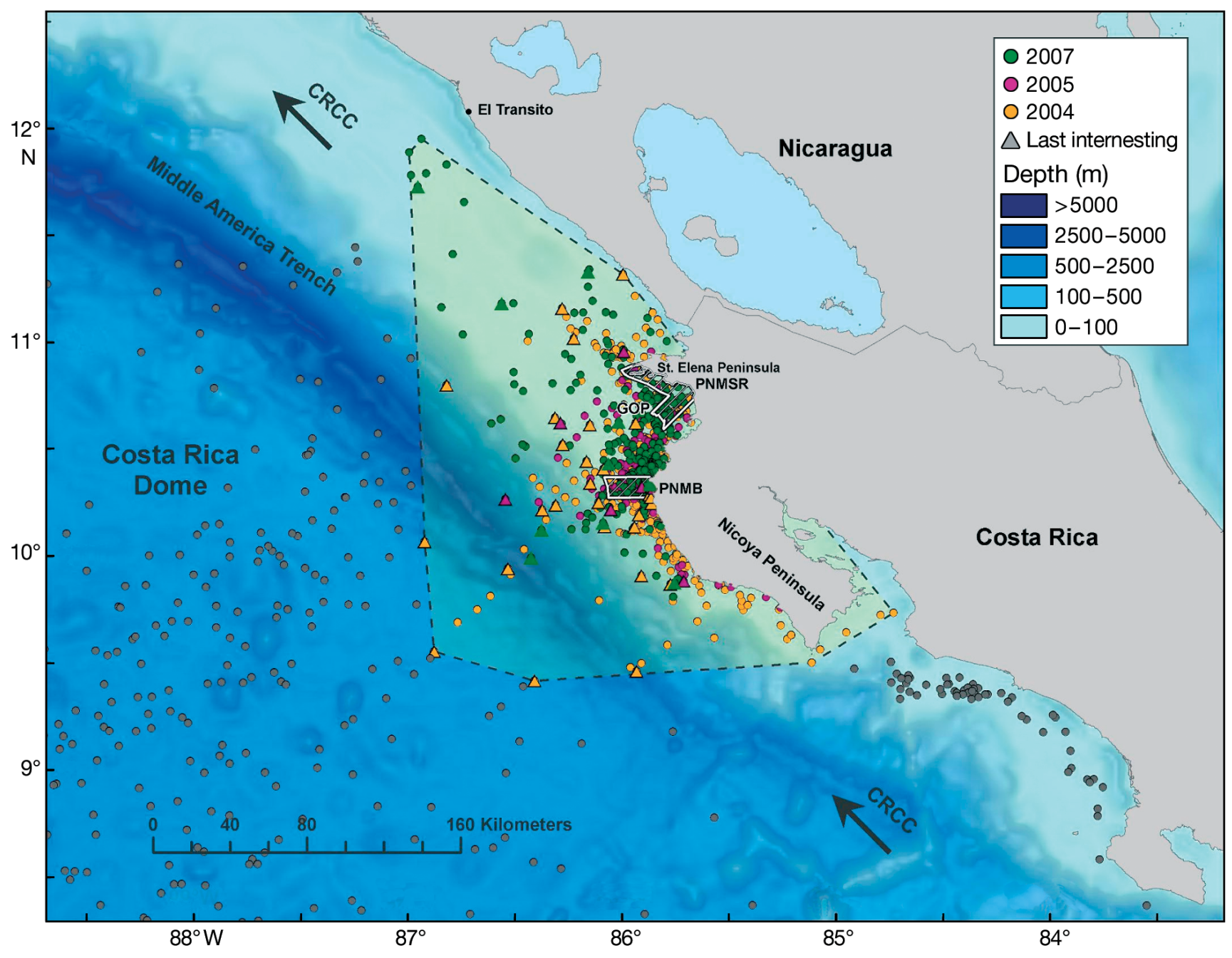

Fig. 1. Dermochelys coriacea. Internesting positions for leatherback turtles during 2004 (O), 2005 (O) and 2007 (O) overlaid on bathymetry. Triangles demarcate the last internesting position per platform transmitter terminal (PTT) within each of the tracking seasons $(\triangle, 2004 ; \Delta, 2005 ; \Delta, 2007)$. Dashed black line represents $95 \%$ minimum convex polygon (MCP) for combined tracking seasons. Polygons bordered in white are Playa Grande National Marine Park (PNMB) and Santa Rosa National Marine Park (PNMSR). Circles outside of the MCP illustrate how turtle movements continued post-internesting but have been greyed out as they are not considered in the analysis. GOP: Gulf of Papagayo. Costa Rica Coastal Current (CRCC) is denoted with directionality arrows 
tive period (October to March). This is a time when turtles are concentrated within nearshore habitats and can be at risk from fisheries interactions and other anthropogenic pressures. PNMB's marine boundaries extend $22.2 \mathrm{~km}$ (12 nautical miles, $\mathrm{n}$ miles) from the nesting beaches, and the marine sector of the park is managed as a no-take zone for all fishing activity, although the adjacent marine areas are not managed under any type of protected status. In this study, we identify and characterize the interannual variability of high-use internesting habitats of leatherback turtles satellite-tagged at Playa Grande, Costa Rica. The identification of high-use internesting habitats through electronic tracking studies will help to refine measures aimed at mitigating human impacts on leatherback turtles and will provide insights into the degree to which the current marine protected area, PNMB, encompasses critical internesting habitats for this endangered species.

\section{MATERIALS AND METHODS}

Tagging and data processing. Sea Mammal Research Unit (SMRU) satellite relay data logger (SRDL) tags were attached to 36 female leatherback turtles during $2004(n=17), 2005(n=8)$ and $2007(n=11)$. The SRDL tags were programmed to collect and transmit position, temperature, dive data and tag diagnostic information. An additional 10 turtles were tagged during 2004 with wildlife computer smart position only tags (SPOTs), which were programmed to provide position data. The satellite transmitters were mounted on the turtles during oviposition by means of a harness (Eckert 2002). Data from the tags were transmitted via the Argos satellite system. A state-space model (SSM), which can account for different location class errors, was applied to all of these raw Argos-acquired locations to produce final position estimates at regular $6 \mathrm{~h}$ intervals to improve position accuracy and to align with SMRU summary dive data (Jonsen et al. 2003, Bailey et al. 2008, Shillinger et al. 2008) (Fig. 1). The application of a switching SSM provided the capacity to discern between 2 behavioral modes based on a first-difference correlated random walk. The location of the switch between these 2 behavioral modes was used to objectively define the transition from internesting ('mode 2 ') to the postnesting migration ('mode 1') (Bailey et al. 2008). In the few cases where a clear switch was not present, a sudden increase in the travel speed was used to determine the cut-off point. Travel speeds were calculated by first-differencing consecutive 6-h SSM mean position estimates. To align with environmental data that were only available on a daily basis, the median of the four 6-h SSM mean positions was calculated for each day.
Dive data were obtained from a pressure sensor on the SRDL tags (to accuracy of $0.33 \mathrm{~m}$ ). Dive initiation and termination were determined by the tag's conductivity sensor. Profiles were recorded for all dives deeper than $10 \mathrm{~m}$. Bespoke software onboard the tag was used to examine dive profiles and identify 5 significant inflection points within the dive (Fedak et al. 2002). Information about the geoposition of dive profiles, dive start and end times and dive profile inflection points was provided, along with maximum dive depth attained on individual dives, summary dive data (e.g. proportion of time spent diving below $10 \mathrm{~m}$, mean dive depths and durations for dives below $10 \mathrm{~m}$ ) in $6 \mathrm{~h}$ bins and tag diagnostic information (Fedak et al. 2002, Hays et al. 2004). The tag summary and diagnostic information was used to filter inaccurate dive profiles from the dive tables within SMRU-developed database queries. Dives that occurred from 06:00 to 18:00 h local time were considered day dives and those after 18:00 h to before $06: 00 \mathrm{~h}$ local time were considered night dives. Differences in dive behavior between day and night were tested with a 2 sample $t$-test.

Sea surface temperature (SST) measurements were extracted from the temperature-at-depth data transmitted by the SRDL tags (resolution to $0.1^{\circ} \mathrm{C}$ ). Surface was considered to be the first depth bin (mean $=5.1 \mathrm{~m}$, $\mathrm{SD}=0.7 \mathrm{~m}$ ). A total of 917 temperature measurements were available after we discarded 105 records because the first depth was missing, had a negative value or had spurious position values. The $1 \mathrm{~m}$ interval temperature-at-depth data were obtained by Loess filtering the 12 temperature-at-depth points provided by the tag. These data were used to produce log frequency temperature-depth plots. For each $1 \mathrm{~m}$ depth interval the temperature at peak use was identified and fit with a third order polynomial.

The turtle morphological and life history information was obtained from field data recorded by research teams coordinated through the Goldring Marine Biology Field Station, including Drexel University, Indiana Purdue-Fort Wayne University, and MINEAT, Costa Rica. The tagged turtles had a mean curved carapace length (CCL) of $145.5 \mathrm{~cm}$, mean estimated clutch frequency (Steyermark et al. 1996, Reina et al. 2002) of 8 clutches and mean clutch size of 60 eggs (Table 1). All internesting periods defined within this paper were recorded by observers on beach patrols at PNMB.

Environmental data. Monthly SST $\left({ }^{\circ} \mathrm{C}\right)$ composites were obtained from the NOAA GOES Imager $\left(0.05^{\circ} \mathrm{spa}-\right.$ tial resolution) for the months of December (2003, 2004 and 2006) and January to March (2004, 2005 and 2007), the main nesting period for our tagged turtles. Monthly composites for net primary productivity (NPP) were obtained from Aqua Modis at $0.05^{\circ}$ spatial resolution (available at http://coastwatch.pfeg.noaa.gov/data.html) 
Table 1. Dermochelys coriacea. Biological data for leatherback turtles satellite tagged at Playa Grande, Costa Rica, during 2004 $(\mathrm{n}=27), 2005(\mathrm{n}=8)$ and $2007(\mathrm{n}=11)$. Mean values for each year and all years combined are in bold text. PTT ID: tag identification number; CCL: caudal carapace length; CCW: caudal carapace width; ECF: estimated clutch frequency; na: data not available

\begin{tabular}{|c|c|c|c|c|c|c|c|c|c|}
\hline PTT ID & $\begin{array}{l}\text { CCL } \\
(\mathrm{cm})\end{array}$ & $\begin{array}{l}\mathrm{CCW} \\
(\mathrm{cm})\end{array}$ & $\begin{array}{l}\text { No. of } \\
\text { clutches }\end{array}$ & $\mathrm{ECF}$ & $\begin{array}{l}\text { Clutch size } \\
\text { (no. of eggs) }\end{array}$ & $\begin{array}{l}\text { Da } \\
\text { First nest }\end{array}$ & Last nest & $\begin{array}{c}\text { First season } \\
\text { observed }\end{array}$ & $\begin{array}{c}\text { Years } \\
\text { observed }\end{array}$ \\
\hline \multicolumn{10}{|l|}{2004} \\
\hline 37595 & 144.6 & 104.5 & 3 & 9.8 & 53.0 & $13 \mathrm{Nov}$ & 4 Feb & $2003 / 04$ & 1 \\
\hline 37596 & 148.4 & 104.2 & 10 & 10.0 & 59.0 & $21 \mathrm{Nov}$ & $15 \mathrm{Feb}$ & $1994 / 95$ & 5 \\
\hline 40672 & 149.2 & 105.5 & 8 & 8.0 & 57.3 & $8 \mathrm{Dec}$ & 18 Feb & $2000 / 01$ & 2 \\
\hline 40673 & 146.5 & 105.4 & 4 & 5.8 & 78.0 & $29 \mathrm{Dec}$ & 12 Feb & $1998 / 99$ & 3 \\
\hline 40675 & 142.8 & 102.3 & 5 & 5.0 & na & $10 \mathrm{Jan}$ & $18 \mathrm{Feb}$ & $2000 / 01$ & 2 \\
\hline 41687 & 143.9 & 103.1 & 5 & 7.3 & na & $9 \mathrm{Dec}$ & 6 Feb & $2003 / 04$ & 1 \\
\hline 41688 & 148.9 & 106.3 & 7 & 7.0 & 79.3 & $7 \mathrm{Dec}$ & 31 Jan & $2003 / 04$ & 1 \\
\hline 41689 & 145.8 & 107.3 & 11 & 11.0 & 61.0 & $6 \mathrm{Nov}$ & 9 Feb & $2000 / 01$ & 2 \\
\hline 41690 & 140.0 & 103.2 & 8 & 8.0 & 74.5 & $29 \mathrm{Nov}$ & 7 Feb & $2000 / 01$ & 2 \\
\hline 41691 & 157.4 & 106.9 & 9 & 9.0 & 43.3 & $13 \mathrm{Nov}$ & $30 \mathrm{Nov}$ & $1994 / 95$ & 3 \\
\hline 41692 & 141.1 & 97.3 & 4 & 6.1 & 71.0 & $12 \mathrm{Dec}$ & $1 \mathrm{Feb}$ & $2003 / 04$ & 1 \\
\hline 41693 & 140.6 & 99.8 & 5 & 4.1 & 80.0 & 18 Jan & 16 Feb & $2003 / 04$ & 1 \\
\hline 41694 & 148.0 & 103.4 & 5 & 5.0 & 82.0 & 8 Jan & $18 \mathrm{Feb}$ & $2003 / 04$ & 1 \\
\hline 41695 & 151.3 & 105.4 & 7 & 7.0 & 59.3 & $17 \mathrm{Nov}$ & 19 Jan & $1995 / 96$ & 3 \\
\hline 41696 & 148.2 & 107.4 & 9 & 9.0 & 65.5 & $7 \mathrm{Nov}$ & $19 \mathrm{Jan}$ & 1997/98 & 3 \\
\hline 41697 & 139.4 & 101.2 & 8 & 8.0 & 73.0 & $6 \mathrm{Dec}$ & 13 Feb & $2000 / 01$ & 2 \\
\hline 41698 & 151.3 & 108.4 & 9 & 9.0 & 79.5 & $27 \mathrm{Nov}$ & $12 \mathrm{Feb}$ & $1999 / 00$ & 2 \\
\hline 41699 & 133.5 & 96.7 & 9 & 9.0 & 67.0 & $25 \mathrm{Nov}$ & 2 Feb & $2003 / 04$ & 1 \\
\hline 41700 & 142.1 & 103.1 & 8 & 7.1 & na & $14 \mathrm{Dec}$ & $6 \mathrm{Feb}$ & $2000 / 01$ & 2 \\
\hline 41701 & 154.8 & 112.5 & 11 & 11.2 & 63.3 & $6 \mathrm{Nov}$ & 6 Feb & $1999 / 00$ & 2 \\
\hline 41702 & 148.1 & 108.8 & 14 & 13.9 & 62.0 & 15 Oct & $13 \mathrm{Feb}$ & $2000 / 01$ & 2 \\
\hline 41703 & 138.2 & 98.1 & 7 & 7.0 & na & $14 \mathrm{Dec}$ & $11 \mathrm{Feb}$ & $2003 / 04$ & 1 \\
\hline 41704 & 144.6 & 106.8 & 5 & 6.0 & 61.0 & $28 \mathrm{Dec}$ & 11 Feb & 1994/95 & 3 \\
\hline 41705 & 139.0 & 100.8 & 6 & 5.8 & 57.7 & $11 \mathrm{Dec}$ & $28 \mathrm{Jan}$ & $2003 / 04$ & 1 \\
\hline 41706 & 143.4 & 103.2 & 8 & 9.1 & 55.2 & $19 \mathrm{Nov}$ & $3 \mathrm{Feb}$ & $2001 / 02$ & 2 \\
\hline 41707 & 126.9 & 96.5 & 5 & 5.0 & 48.7 & $17 \mathrm{Dec}$ & 24 Jan & $2003 / 04$ & 1 \\
\hline 41708 & 136.8 & 104.7 & 11 & 11.0 & 57.0 & $12 \mathrm{Nov}$ & 12 Feb & $2000 / 01$ & 2 \\
\hline 41709 & 137.8 & 99.6 & 11 & 11.2 & 56.0 & 23 Oct & $21 \mathrm{Jan}$ & $2003 / 04$ & 1 \\
\hline 41710 & 146.5 & 100.6 & 8 & 6.0 & 63.0 & $11 \mathrm{Dec}$ & 16 Feb & $2000 / 01$ & 2 \\
\hline 41711 & 145.3 & 105.6 & 4 & 8.9 & na & $16 \mathrm{Dec}$ & 28 Feb & $2003 / 04$ & 1 \\
\hline Mean & 144.1 & 103.6 & 7.5 & 8.0 & 64.3 & & & & 1.9 \\
\hline $\mathrm{SD}$ & 6.3 & 3.8 & 2.7 & 2.3 & 10.5 & & & & 0.9 \\
\hline \multicolumn{10}{|l|}{2005} \\
\hline 56268 & 151.3 & 106.5 & 5 & 8.4 & 39.3 & $29 \mathrm{Nov}$ & 7 Feb & 1994/95 & 3 \\
\hline 56272 & 140.4 & 97.8 & 2 & 3.7 & 53.5 & 4 Jan & 29 Jan & $2004 / 05$ & 1 \\
\hline 56274 & 149.7 & 102.7 & 9 & 10.7 & 43.5 & 30 Oct & $28 \mathrm{Jan}$ & $2000 / 01$ & 2 \\
\hline 56276 & 145.2 & 109.4 & 10 & 9.9 & 58.8 & $11 \mathrm{Nov}$ & 3 Feb & 1999/00 & 3 \\
\hline 56279 & 133.1 & 101.5 & 9 & 9.1 & 64.2 & 7 Dec & $21 \mathrm{Feb}$ & $2000 / 01$ & 2 \\
\hline 56280 & 154.5 & 109.6 & 4 & 5.6 & 64.7 & 17 Jan & 1 Mar & $1994 / 95$ & 4 \\
\hline 56282 & 141.4 & 100.7 & 9 & 9.3 & 61.4 & 2 Dec & $18 \mathrm{Feb}$ & $1994 / 95$ & 3 \\
\hline 56283 & 150.2 & 106.5 & 5 & 5.6 & 71.0 & 7 Jan & $19 \mathrm{Feb}$ & $2004 / 05$ & 1 \\
\hline Mean & 145.7 & 104.3 & 6.6 & 7.8 & 57.1 & & & & 2.4 \\
\hline $\mathrm{SD}$ & 7.1 & 4.3 & 3.0 & 2.5 & 10.9 & & & & 1.1 \\
\hline \multicolumn{10}{|l|}{2007} \\
\hline 72474 & 139.0 & 107.0 & 7 & & 51.0 & $15 \mathrm{Dec}$ & $18 \mathrm{Feb}$ & $1995 / 96$ & 4 \\
\hline 72475 & 143.9 & 106.7 & 7 & 8.9 & 77.0 & $15 \mathrm{Nov}$ & $28 \mathrm{Jan}$ & $2000 / 01$ & 2 \\
\hline 72476 & 153.1 & 111.7 & 11 & 11.6 & 50.0 & $11 \mathrm{Nov}$ & $19 \mathrm{Feb}$ & $2000 / 01$ & 3 \\
\hline 72477 & 156.9 & 107.9 & 11 & 12.0 & 48.5 & $3 \mathrm{Nov}$ & 14 Feb & $2003 / 04$ & 1 \\
\hline 72478 & 142.7 & 103.9 & 8 & 10.5 & 55.3 & $26 \mathrm{Nov}$ & $23 \mathrm{Feb}$ & $1995 / 96$ & 3 \\
\hline 72479 & 165.6 & 115.2 & 9 & 9.3 & 87.7 & $20 \mathrm{Nov}$ & 6 Feb & 1995/96 & 3 \\
\hline 72480 & 155.8 & 109.6 & 10 & 12.5 & 63.5 & $2 \mathrm{Nov}$ & $18 \mathrm{Feb}$ & $1994 / 95$ & 4 \\
\hline 72481 & 149.1 & 99.1 & 4 & 5.7 & 51.0 & 6 Jan & $19 \mathrm{Feb}$ & $1997 / 98$ & 4 \\
\hline 72482 & 146.2 & 103.6 & 8 & 10.8 & 68.4 & $10 \mathrm{Nov}$ & $10 \mathrm{Feb}$ & $1995 / 96$ & 3 \\
\hline 72483 & 142.5 & 102.7 & 2 & 2.1 & na & 3 Feb & 13 Feb & $2006 / 07$ & 1 \\
\hline 72485 & 146.3 & 104.4 & 4.0 & 5.3 & 50.0 & 5 Jan & 14 Feb & $2006 / 07$ & 1 \\
\hline Mean & 149.2 & 106.5 & 7.4 & 8.9 & 60.2 & & & & 2.6 \\
\hline $\mathrm{SD}$ & 7.9 & 4.5 & 3.0 & 3.4 & 13.6 & & & & 1.2 \\
\hline \multicolumn{10}{|l|}{ Mean for } \\
\hline all years & 145.5 & 104.4 & 7.3 & 8.2 & 62.0 & & & & 2.1 \\
\hline $\mathrm{SD}$ & 7.0 & 4.2 & 2.7 & 2.6 & 11.4 & & & & 1.1 \\
\hline
\end{tabular}


for the months of December (2003, 2004 and 2006) and January to March (2004, 2005 and 2007). Bathymetry was extracted from the global sea-floor topography of Smith \& Sandwell (1997; v. 8.2, November 2000; available at http://topex.ucsd.edu/WWW_html/mar_ topo.html). This dataset combines all available depth soundings with high-resolution marine gravity information provided by the Geosat, ERS-1/2 and TOPEX/ Poseidon satellite altimeters, and has a nominal resolution of 2 arc-minutes $(\sim 4 \mathrm{~km})$.

Utilization distribution and minimum convex polygon (MCP) analysis. Geographic information systems software (ArcGIS 9.3 and ArcView 3.3) was used to map turtle movements and delineate high use internesting habitats. High-use habitats were defined by calculating fixed kernel home ranges for all turtles using the median daily SSM-generated positions for each animal. This process involved creating seasonal utilization distribution (UD) maps (Worton 1989) of the data using the Home Range Extension in ArcView. A fixed kernel approach was selected because it provided a better estimate of home-range size than adaptive kernel approaches (Seaman \& Powell 1996), and the least-squares-cross-validation method was used to calculate the smoothing parameter (Worton 1989). The 25, 50, 75 and $95 \%$ UD polygons were created for all turtles for individual years and for all years combined (Fig. 2). The core region was assigned to be the $25 \%$ UD (Hyrenbach et al. 2006), and everything outside of the $25 \%$ UD but contained within the $95 \%$ UD was considered as noncore. We extracted vertical and horizontal turtle movement from the core and noncore regions for our analyses. Kruskal-Wallis tests compared vertical behaviors within the UD polygon core and noncore regions and also between tracking years. A multiple comparison ANOVA was subsequently applied to conduct post hoc pairwise comparisons between the mean ranks. MCPs were created with Hawth's Tools in ArcGIS using a fixed mean selection at $100 \%$ coverage to delineate total internesting habitat use for each turtle within each tracking season, and for all turtles across all 3 tracking seasons.

\section{RESULTS}

\section{Track durations and observed internesting periods}

A total of $1135 \mathrm{~d}$ of internesting movements were recorded (2004: 690 d, 2005: 188 d, 2007: 257 d; Table 2). Across the entire dataset, the tracking period per turtle during the internesting period ranged to $88 \mathrm{~d}$ (mean $=25.8 \mathrm{~d}$, SD = $18.1 \mathrm{~d}$ ). One turtle (tag identification no. 56272) that initiated migration immediately after tagging was eliminated from the internesting dataset. Analyses of internesting durations were potentially reduced by our tag deployment approach, which targeted turtles during the latter part of the nesting season so as to minimize possible stress or interference during the nesting process from the tracking device.

Specific internesting periods were determined by visual observations of nesting events. An analysis of the initial subset of validated internesting intervals $(n=27)$ revealed that these intervals ranged from 9 to $12 \mathrm{~d}$ (mean $=10.1 \mathrm{~d}, \mathrm{SD}=0.9 \mathrm{~d}$ ). Since turtles occasionally nested on beaches without observer coverage and remained within internesting habitats after the end of the field research period (March), it is possible that some nesting events were not recorded. We did not attempt to derive nesting events from satellite tracking location data alone, due to uncertainty associated with possible false crawls or aborted nesting attempts, and the possibility that shallow water dive behavior and surface behavior within nearshore habitats could create a false positive result. Haulout data, based on the length of time the saltwater switch on the satellite tag was dry, provides another method of recording nesting events that deserves attention in future studies (Georges et al. 2007).

\section{Environmental data}

We used a suite of remote sensing data to characterize variability within the internesting habitat. Analysis of SST (Fig. 3) and NPP imagery (Fig. 4), revealed consistent annual surface patterns in SST and productivity within the tracking region as well as in the area ranging to $20^{\circ} \mathrm{N}$. Strong transitions in SST and NPP occurred during the peak of internesting (between December and January) and during the end of internesting (between February and March). The imagery implied strengthening of the Papagayo and Tehauntepec jets (Palacios \& Bograd 2005, Kessler 2006), which forced local upwelling near the Gulf of Papagayo (GOP) and Gulf of Tehauntepec (GOT) and within the internesting MCP (Fig. 2). These jets also contributed to the formation of large and long-lived anti-cyclonic eddies that entrained and exported biogenic material offshore and enhanced productivity throughout the tracking region. The seasonal development of the locally productive Costa Rica Dome (CRD; Kessler 2006) was apparent in both the SST and NPP imagery. During January and February of each tracking year a cold nutrient-rich region located to the north and west and extending into the MCP was apparent. This region remained through March 2007. Along with the overall warmer temperatures during 2007, this cold region contributed to the wider range of temperatures within the MCP during 2007. The thermal signal from the Costa Rica Coastal Current (CRCC) within the SST 

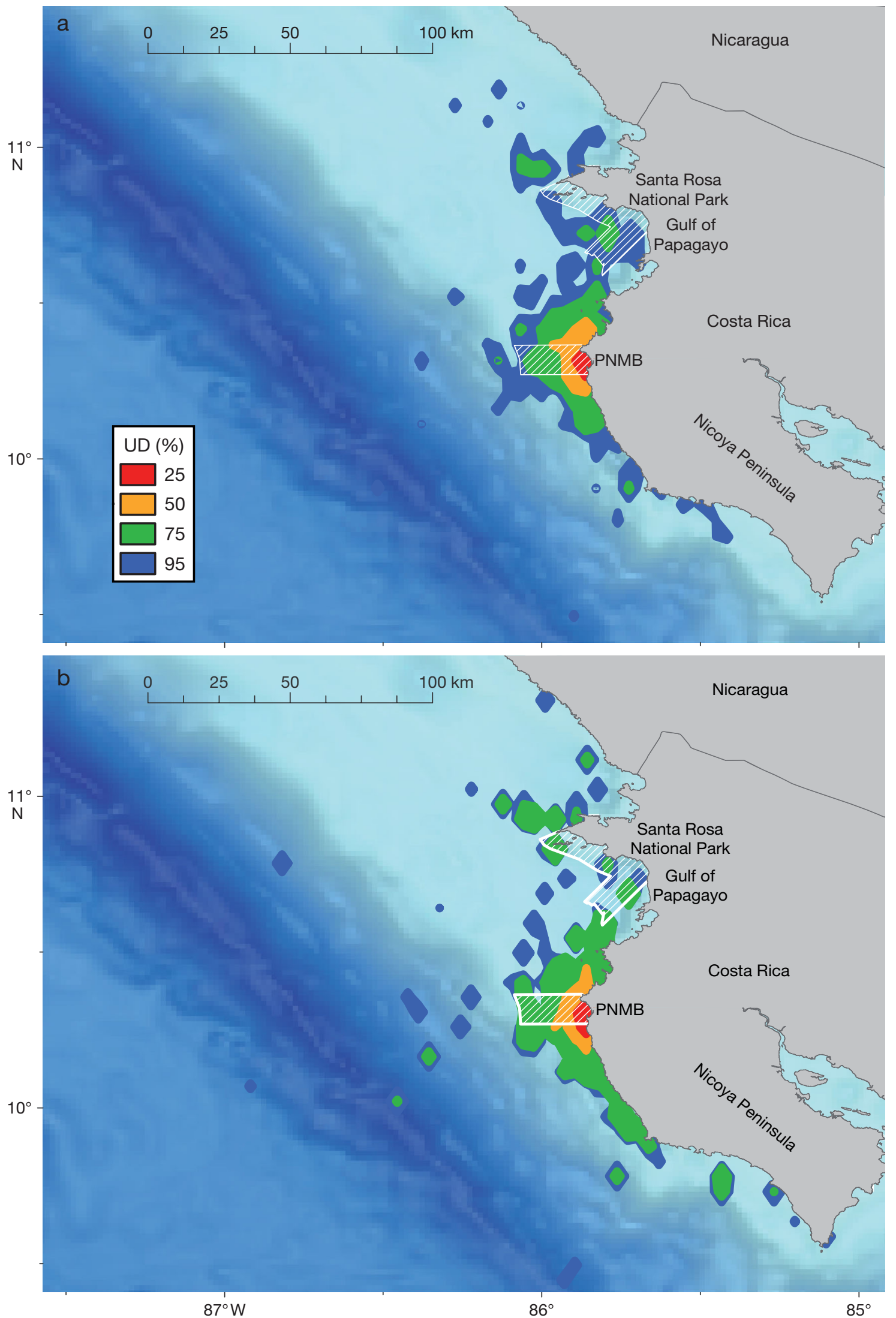

Fig. 2. Dermochelys coriacea. Utilization distribution (UD) of internesting region occupied by 46 leatherback turtles during (a) all years combined, (b) 2004 ( $\mathrm{n}=27$ ), (c) 2005 ( $\mathrm{n}=8$ ) and (d) $2007(\mathrm{n}=11)$. Polygons bordered and cross-hatched in white are Playa Grande National Marine Park (PNMB) and Santa Rosa National Marine Park (PNMSR). See Fig. 1 for bathymetry details 

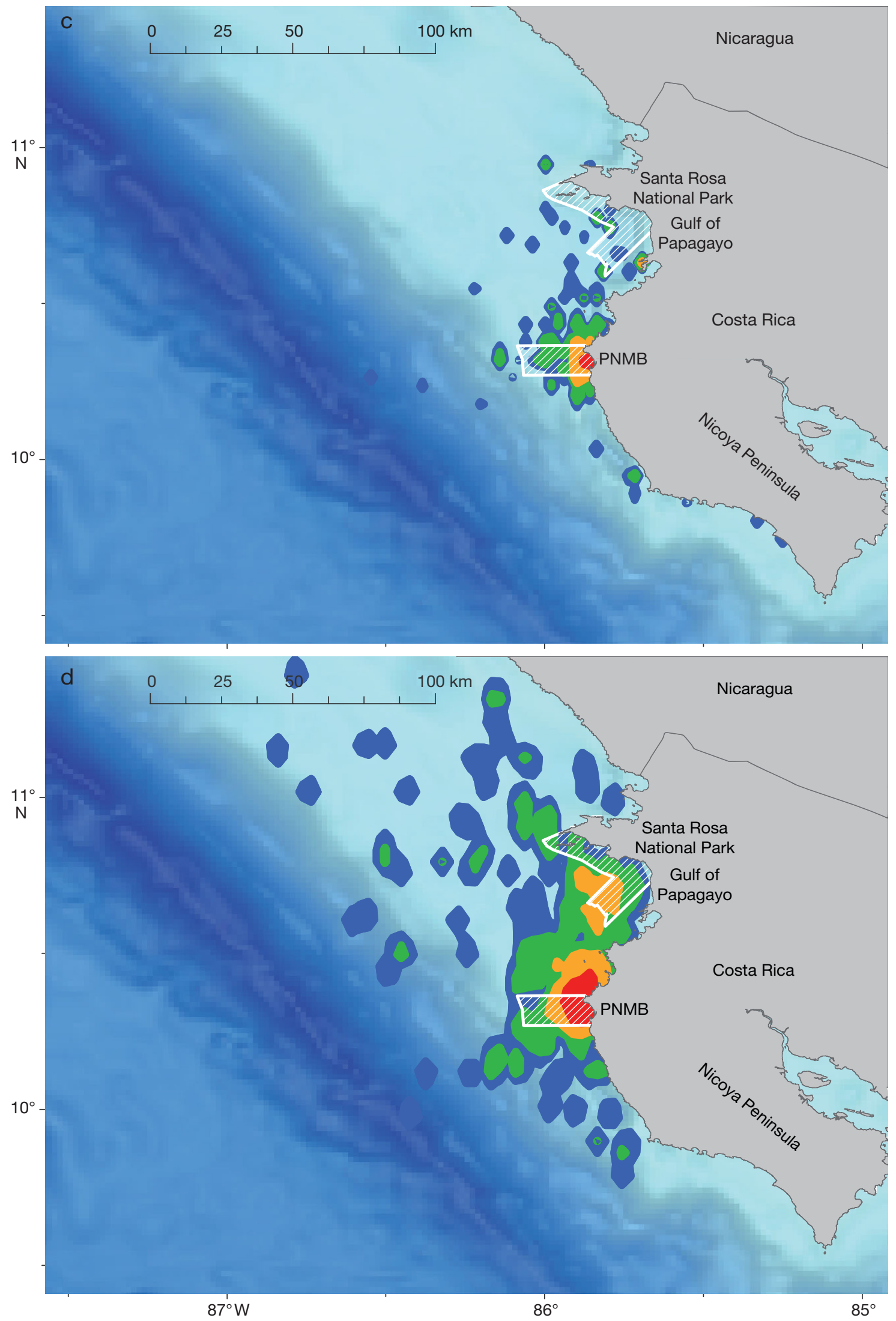

Fig. 2 (continued) 
Table 2. Dermochelys coriacea. Horizontal movement data for leatherback turtles satellite tagged at Playa Grande, Costa Rica, during 2004 ( $\mathrm{n}=$ $27), 2005(\mathrm{n}=8)$ and $2007(\mathrm{n}=11)$. A single location $\left(85.82^{\circ} \mathrm{W}, 10.31^{\circ} \mathrm{N}\right)$ on the nesting beach was used as a reference point for calculating the minimum convex hull polygons (MCP), the convex hulls and maximum distance range calculations, and the maximum and minimum latitudinal and longitudinal range calculations. Sea surface temperature $\left(\mathrm{SST},{ }^{\circ} \mathrm{C}\right)$ was extracted from the SMRU SRDL tag-derived data for the $1 \mathrm{~m}$ depth bin. Mean values for each year are in bold text. PTT ID: tag identification no.; Total rec. days: total no. of days recorded; na: data not available

\begin{tabular}{|c|c|c|c|c|c|c|c|c|c|c|c|c|c|}
\hline \multirow[t]{2}{*}{ PTT ID } & \multirow[t]{2}{*}{$\begin{array}{l}\text { Tagging } \\
\text { date }\end{array}$} & \multirow[t]{2}{*}{$\begin{array}{l}\text { Internesting } \\
\text { end date }\end{array}$} & \multirow{2}{*}{$\begin{array}{l}\text { Total } \\
\text { rec. } \\
\text { days }\end{array}$} & \multirow{2}{*}{$\begin{array}{l}\text { Observed } \\
\text { internesting } \\
\text { periods }\end{array}$} & \multirow{2}{*}{$\begin{array}{c}\text { Total } \\
\text { distance } \\
\text { travelled } \\
(\mathrm{km})\end{array}$} & \multirow{2}{*}{$\begin{array}{c}\text { Mean } \\
\text { speed } \\
\left(\mathrm{km} \mathrm{d}^{-1}\right)\end{array}$} & \multirow{2}{*}{$\begin{array}{l}95 \% \\
\mathrm{MCP} \\
\left(\mathrm{km}^{2}\right)\end{array}$} & \multirow{2}{*}{$\begin{array}{c}\text { Max. } \\
\text { range } \\
(\mathrm{km})\end{array}$} & \multicolumn{2}{|c|}{$\begin{array}{c}\text { Lat. range } \\
\left({ }^{\circ} \mathrm{N}\right)\end{array}$} & \multicolumn{2}{|c|}{$\begin{array}{c}\text { Long. range } \\
\left({ }^{\circ} \mathrm{W}\right)\end{array}$} & \multirow{2}{*}{$\begin{array}{l}\text { Mean } \\
\text { SST } \\
\left({ }^{\circ} \mathrm{C}\right)\end{array}$} \\
\hline & & & & & & & & & Max. & Min. & Max. & Min. & \\
\hline \multicolumn{14}{|l|}{2004} \\
\hline 37595 & 26 Jan & $24 \mathrm{Feb}$ & 30 & 1 & 130.20 & 4.34 & 958.07 & 47.38 & 10.4760 & 10.0061 & 85.9928 & 85.7569 & 27.69 \\
\hline 37596 & $26 \mathrm{Jan}$ & $28 \mathrm{Feb}$ & 33 & 2 & 61.50 & 1.86 & 194.78 & 11.40 & 10.3339 & 10.2799 & 85.9349 & 85.8438 & 27.60 \\
\hline 41687 & $27 \mathrm{Jan}$ & $20 \mathrm{Feb}$ & 23 & 1 & 81.57 & 3.55 & 5957.11 & 97.35 & 10.1752 & 10.1752 & 86.2265 & 85.8832 & na \\
\hline 41688 & $20 \mathrm{Jan}$ & $4 \mathrm{Feb}$ & 14 & 1 & 75.04 & 5.36 & 4727.67 & 66.45 & 10.7285 & 10.3933 & 85.9137 & 85.7588 & na \\
\hline 41689 & $30 \mathrm{Jan}$ & 15 Feb & 16 & 1 & 42.50 & 2.66 & 724.89 & 30.52 & 10.5582 & 10.2030 & 85.9640 & 85.8312 & na \\
\hline 41690 & $28 \mathrm{Jan}$ & 4 Mar & 36 & 1 & 120.11 & 3.34 & 1400.13 & 49.23 & 10.5582 & 10.2334 & 86.0202 & 85.8492 & na \\
\hline 41691 & $30 \mathrm{Jan}$ & $25 \mathrm{Feb}$ & 25 & 0 & 127.62 & 5.11 & 1728.62 & 59.84 & 10.4094 & 10.2395 & 86.3613 & 85.8636 & na \\
\hline 41692 & 1 Feb & $12 \mathrm{Feb}$ & 11 & 0 & 83.33 & 7.58 & 2020.07 & 66.30 & 10.7128 & 10.3404 & 85.9888 & 85.8092 & na \\
\hline 41693 & $16 \mathrm{Jan}$ & $23 \mathrm{Mar}$ & $35^{\mathrm{a}}$ & 0 & 119.96 & 3.43 & 1390.85 & 31.33 & 10.5910 & 10.2094 & 86.0019 & 85.8344 & na \\
\hline 41694 & 18 Jan & 29 Feb & $10^{\mathrm{a}}$ & 0 & 38.06 & 3.81 & 2373.32 & 89.55 & 11.1219 & 10.8708 & 85.9977 & 85.8431 & na \\
\hline 41695 & 19 Jan & $23 \mathrm{Feb}$ & 33 & 0 & 137.44 & 4.16 & 3830.69 & 121.58 & 10.5018 & 9.8628 & 86.5656 & 85.7593 & na \\
\hline 41696 & 19 Jan & $30 \mathrm{Jan}$ & 10 & 0 & 47.94 & 4.79 & 1389.88 & 102.02 & 10.9844 & 10.7164 & 86.0562 & 85.9638 & na \\
\hline 41697 & $27 \mathrm{Jan}$ & $15 \mathrm{Mar}$ & 48 & 2 & 153.54 & 3.20 & 975.33 & 46.15 & 10.7267 & 10.1854 & 85.9009 & 85.7345 & 27.65 \\
\hline 41698 & 23 Jan & 16 Feb & 24 & 2 & 103.12 & 4.30 & 754.38 & 49.36 & 10.7091 & 10.2993 & 85.9036 & 85.6932 & 27.04 \\
\hline 41699 & 24 Jan & 15 Feb & 22 & 2 & 74.47 & 3.34 & 431.85 & 34.65 & 10.3483 & 10.2247 & 85.9990 & 85.8522 & 27.03 \\
\hline 41700 & 29 Jan & $16 \mathrm{Mar}$ & 49 & 1 & 150.98 & 3.08 & 556.44 & 42.67 & 10.4167 & 10.0360 & 86.0065 & 85.7361 & 27.19 \\
\hline 41701 & 29 Jan & 10 Feb & 12 & 1 & 30.83 & 2.57 & 150.97 & 14.37 & 10.4148 & 10.2546 & 85.9217 & 85.8367 & 27.55 \\
\hline 41702 & $24 \mathrm{Jan}$ & 6 Feb & 13 & 1 & 85.34 & 6.56 & 4156.83 & 56.24 & 10.7135 & 10.3129 & 85.8973 & 85.7425 & 27.30 \\
\hline 41703 & 23 Jan & $20 \mathrm{Mar}$ & 58 & 2 & 196.46 & 3.39 & 739.76 & 46.03 & 10.3212 & 10.0404 & 85.9009 & 85.8127 & 27.41 \\
\hline 41704 & $23 \mathrm{Jan}$ & 20 Feb & 28 & 2 & 163.78 & 5.85 & 2522.19 & 163.78 & 11.1297 & 10.1222 & 86.0234 & 85.7887 & 27.03 \\
\hline 41705 & 29 Jan & $11 \mathrm{Feb}$ & 13 & 0 & 122.85 & 9.45 & 5366.04 & 141.16 & 10.3126 & 9.5315 & 85.8528 & 85.8161 & 28.33 \\
\hline 41706 & $25 \mathrm{Jan}$ & $17 \mathrm{Feb}$ & 22 & 1 & 105.82 & 4.81 & 964.13 & 49.32 & 10.3880 & 10.1388 & 85.9356 & 85.8161 & 27.52 \\
\hline 41707 & $25 \mathrm{Jan}$ & $31 \mathrm{Jan}$ & 6 & 0 & 107.74 & 17.96 & 3018.43 & 117.77 & 10.0254 & 9.8892 & 85.7597 & 85.3876 & 27.97 \\
\hline 41708 & $25 \mathrm{Jan}$ & $25 \mathrm{Feb}$ & 31 & 2 & 171.11 & 5.52 & 1057.65 & 106.54 & 10.3751 & 9.6880 & 85.9123 & 85.3193 & 27.76 \\
\hline 41709 & $22 \mathrm{Jan}$ & 3 Feb & 12 & 0 & 57.16 & 4.76 & 2150.50 & 76.61 & 10.9864 & 10.6040 & 86.0839 & 85.9437 & 26.44 \\
\hline 41710 & 27 Jan & 29 Feb & 34 & 2 & 261.87 & 7.70 & 2006.53 & 78.48 & 10.5691 & 9.8037 & 86.1323 & 85.4788 & 26.82 \\
\hline 41711 & 27 Jan & $23 \mathrm{Apr}$ & 88 & 2 & 495.07 & 5.63 & 3922.42 & 106.37 & 10.5153 & 9.6387 & 85.9025 & 85.2329 & 26.72 \\
\hline Mean & & & 27.6 & 1.00 & 123.90 & 5.11 & 2054.43 & 70.46 & & & & & 27.36 \\
\hline SD & & & 18.3 & 0.83 & 91.00 & 3.10 & 1626.47 & 38.51 & & & & & 0.48 \\
\hline \multicolumn{14}{|l|}{2005} \\
\hline 56268 & 8 Feb & $26 \mathrm{Mar}$ & 46 & 0 & 213.82 & 4.65 & 3492.52 & 74.10 & 10.8531 & 10.2915 & 86.0926 & 85.7291 & 27.73 \\
\hline 56272 & 29 Jan & 29 Jan & 0 & 0 & na & na & na & na & na & na & na & na & na \\
\hline 56274 & $28 \mathrm{Jan}$ & $8 \mathrm{Feb}$ & 11 & 0 & 12.03 & 1.09 & 81.92 & 14.19 & 10.3636 & 10.2786 & 85.9894 & 85.8580 & 27.83 \\
\hline 56276 & 4 Feb & 5 Mar & 29 & 0 & 200.52 & 6.91 & 1162.75 & 69.12 & 10.8074 & 10.3211 & 85.9418 & 85.8245 & 27.05 \\
\hline 56279 & $11 \mathrm{Feb}$ & 23 Feb & 12 & 1 & 26.18 & 2.18 & 363.32 & 26.18 & 10.5518 & 10.3188 & 85.9918 & 85.8684 & 26.80 \\
\hline 56280 & 8 Feb & $23 \mathrm{Mar}$ & 43 & 2 & 129.60 & 3.01 & 581.94 & 50.18 & 10.4166 & 9.9909 & 85.9711 & 85.7818 & 27.95 \\
\hline 56282 & $30 \mathrm{Jan}$ & 18 Feb & 19 & 2 & 64.48 & 3.39 & 181.82 & 15.53 & 10.2628 & 10.2628 & 85.9453 & 85.8615 & 27.19 \\
\hline 56283 & 9 Feb & 9 Mar & 28 & 2 & 269.65 & 9.63 & 4417.45 & 92.35 & 10.7424 & 9.8058 & 86.2213 & 85.3738 & 27.86 \\
\hline Mean & & & 23.5 & 0.88 & 130.90 & 4.41 & 1468.82 & 48.81 & & & & & 27.49 \\
\hline $\mathrm{SD}$ & & & 16.0 & 0.99 & 100.40 & 2.96 & 1754.61 & 31.01 & & & & & 0.46 \\
\hline 2007 & & & & & & & & & & & & & \\
\hline 72474 & 29 Jan & 8 Feb & 10 & 0 & 84.70 & 8.47 & 676.18 & 52.72 & 10.7364 & 10.4505 & 85.9156 & 85.7481 & 28.04 \\
\hline 72475 & 29 Jan & 29 Jan & 1 & 0 & na & na & na & na & na & na & na & na & 31.26 \\
\hline 72476 & 31 Jan & 3 Mar & 31 & 2 & 247.63 & 7.99 & 3095.47 & 87.41 & 10.9591 & 10.2535 & 86.2514 & 85.7679 & 27.11 \\
\hline 72477 & $3 \mathrm{Feb}$ & $20 \mathrm{Feb}$ & 17 & 1 & 143.96 & 8.47 & 3848.25 & 117.26 & 11.1386 & 10.3140 & 86.1476 & 85.8862 & 28.07 \\
\hline 72478 & 3 Feb & 3 Apr & 59 & 2 & 315.64 & 5.35 & 3169.82 & 116.09 & 11.1658 & 10.2856 & 86.2141 & 85.7627 & 26.88 \\
\hline 72479 & 7 Feb & 1 Mar & 22 & 0 & 92.48 & 4.20 & 600.76 & 52.54 & 10.0717 & 10.0717 & 85.9879 & 85.8136 & 28.07 \\
\hline 72480 & 8 Feb & 2 Mar & 22 & 1 & 232.57 & 10.57 & 11038.96 & 214.91 & 11.8906 & 10.5324 & 86.9532 & 85.8002 & 27.89 \\
\hline 72481 & 9 Feb & $13 \mathrm{Apr}$ & 62 & 1 & 273.91 & 4.42 & 1203.23 & 36.21 & 10.5785 & 10.3215 & 86.0267 & 85.8030 & 28.91 \\
\hline 72482 & $10 \mathrm{Feb}$ & $14 \mathrm{Feb}$ & 4 & 0 & 7.84 & 1.95 & 878.22 & 23.71 & 10.2519 & 10.2519 & 86.0025 & 86.0025 & 28.83 \\
\hline 72483 & $14 \mathrm{Feb}$ & 2 Mar & 16 & 0 & 167.19 & 10.45 & 6327.43 & 90.91 & 10.8311 & 10.1914 & 86.5341 & 85.8567 & 29.02 \\
\hline 72485 & 15 Feb & $28 \mathrm{Feb}$ & 13 & 0 & 62.65 & 4.82 & 1320.97 & 46.19 & 10.2702 & 10.0579 & 86.1254 & 85.8973 & 28.48 \\
\hline Mean & & & 23.4 & 0.64 & 162.86 & 6.67 & 3215.93 & 83.79 & & & & & 28.41 \\
\hline $\mathrm{SD}$ & & & 20.2 & 0.81 & 101.78 & 2.91 & 3294.67 & 56.42 & & & & & 1.17 \\
\hline
\end{tabular}




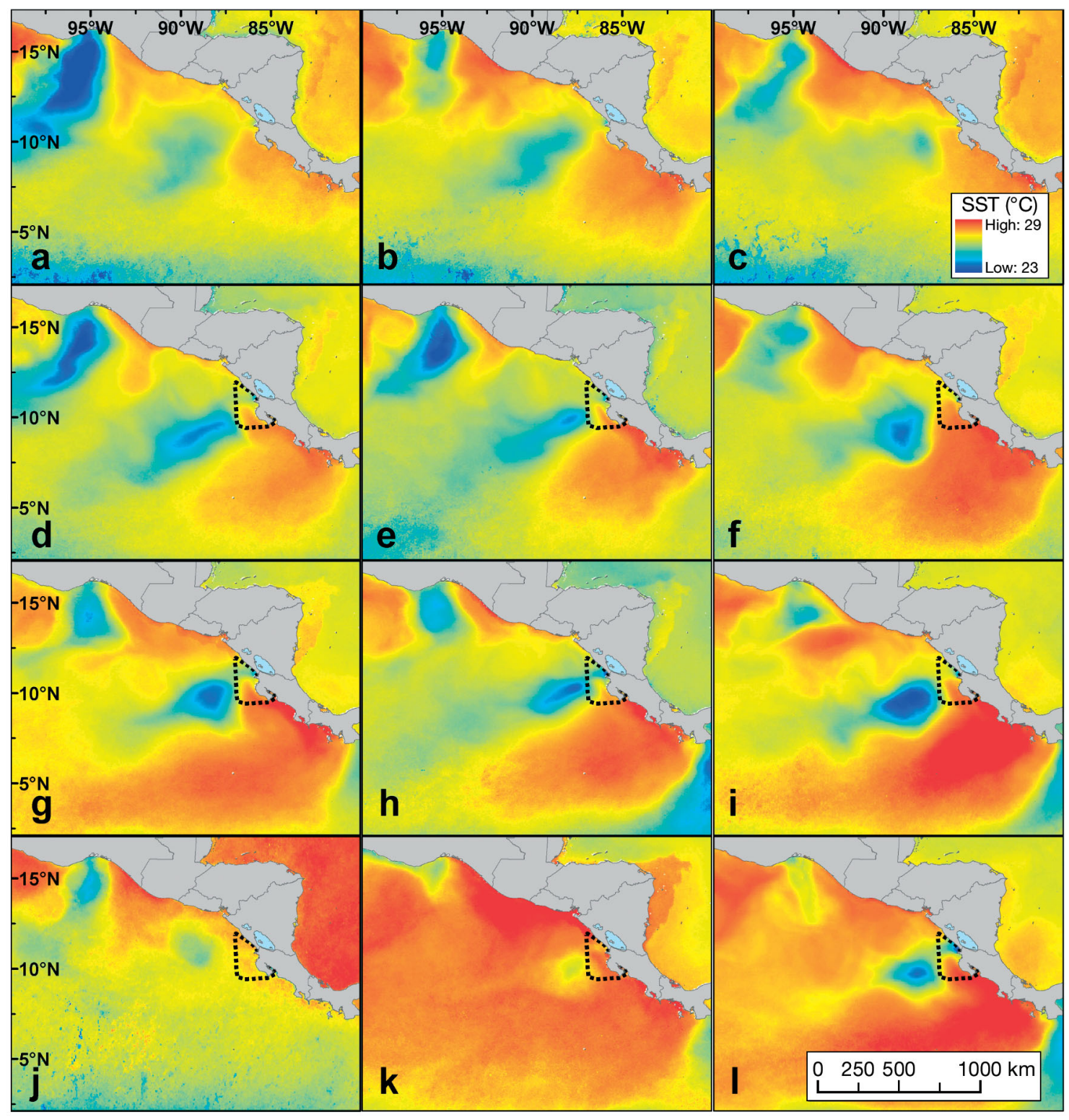

Fig. 3. Dermochelys coriacea. Monthly composite of mean sea surface temperatures $\left(\mathrm{SST},{ }^{\circ} \mathrm{C}\right)$ within the eastern Pacific region surrounding and encompassing the internesting region delineated by the minimum convex polygon (MCP) in Fig. 1, during (a) December 2004, (b) December 2005, (c) December 2007, (d) January 2004, (e) January 2005, (f) January 2007, (g) February 2004, (h) February 2005, (i) February 2007, (j) March 2004, (k) March 2005 and (l) March 2007. Dotted black line represents the MCP for turtle internesting habitat during 3 combined seasons. Images from NOAA GOES Imager, day and night, $0.05^{\circ}$, western hemisphere

imagery implied that this current's influence was stronger during 2007 than during 2004 and 2005.

\section{Horizontal movements}

The MCP derived from the turtle internesting geoposition data for all seasons covered $33542 \mathrm{~km}^{2}$ and spanned from $11.95^{\circ} \mathrm{N}$ to $9.42^{\circ} \mathrm{N}$ and from $84.73^{\circ} \mathrm{W}$ to $86.99^{\circ} \mathrm{W}$ (Fig. 2). Internesting turtles ranged as far south as the southernmost point of the Nicoya Peninsula (Cabo Blanco National Park), east into the Gulf of Nicoya (approximately $28 \mathrm{~km}$ south of Puntarenas) and north to coastal habitats within $30 \mathrm{~km}$ offshore from the beachfront town of El Transito, Nicaragua. Although latitudinal movements did not vary significantly across years (Kruskal-Wallis $H=1.7, \mathrm{p}=0.40$ ), longitudinal movements during 2007 were significantly different (farther offshore) from those of 2004 and 2005 (Kruskal-Wallis $H=10.6, \mathrm{p}<0.01$ ). Across all 3 track- 


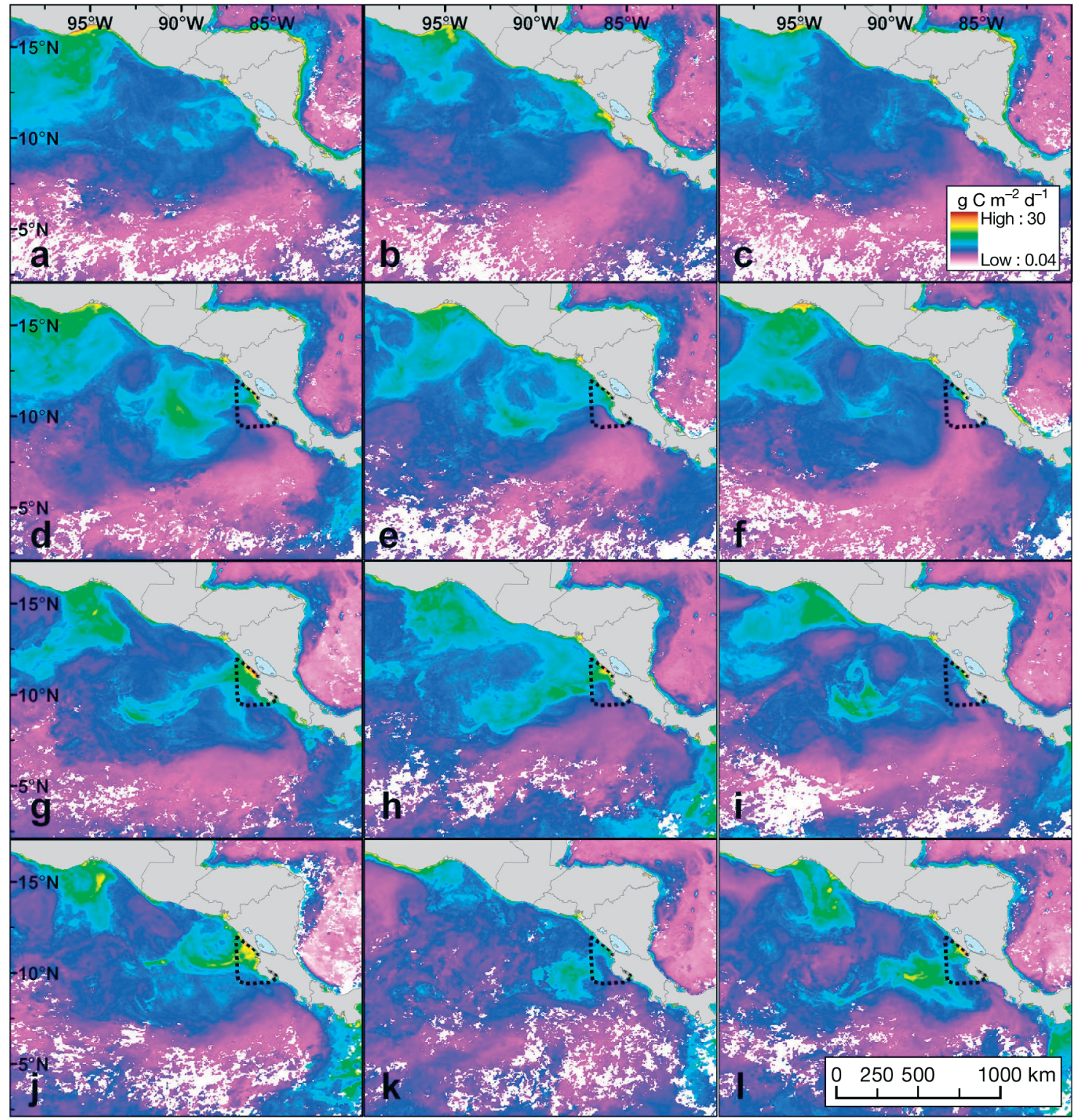

Fig. 4. Dermochelys coriacea. Monthly composite of mean net primary productivity (NPP, $\mathrm{g} \mathrm{C} \mathrm{m}^{-2} \mathrm{~d}^{-1}$ ) within internesting region during (a) December 2004, (b) December 2005, (c) December 2007, (d) January 2004, (e) January 2005, (f) January 2007, (g) February 2004, (h) February 2005, (i) February 2007, (j) March 2004, (k) March 2005 and (l) March 2007. Dotted black line represents minimum convex polygon (MCP) for turtle internesting habitat during 3 combined seasons. Images from Aqua Modis at $0.05^{\circ}$ spatial resolution (available at http://coastwatch.pfeg.noaa.gov/data.html)

ing seasons, the mean maximum distance that internesting turtles traveled from their tag deployment location was $70.1 \mathrm{~km}(\mathrm{SD}=42.6 \mathrm{~km})$ and mean daily speeds ranged from 1.1 to $18.0 \mathrm{~km} \mathrm{~d}^{-1}$ (mean $=5.4$, $\mathrm{SD}=3.1 \mathrm{~km} \mathrm{~d}^{-1}$ ) (Table 2). Turtle speeds were not significantly different between tracking years (KruskalWallis $H=4.5, \mathrm{p}=0.10$ ). The maximum distance traveled from the tagging location $(214.2 \mathrm{~km})$ and the greatest area covered $\left(11039.96 \mathrm{~km}^{2}\right)$ occurred during 2007 when the majority of turtles tended to move north into the Gulf of Papagayo and near the Santa Elena Peninsula (Fig. 2). However, the distances traveled and total area covered were not significantly different (Kruskal-Wallis $H=1.9$ and 2.9, p $=0.40$ and 0.23 , respectively) across years.

The UD analysis of the internesting data revealed that the 25, 50, 75 and 95\% UD polygons for all years encompassed 27.4, 187.9, 685.0 and $2092.2 \mathrm{~km}^{2}$, respectively (Fig. 2). Although there was considerable interannual variation in shape and area of the UD poly- 
gons, the core $25 \%$ UD remained predominantly centered within PNMB during each tracking year. During every tracking season waters within and immediately adjacent to the PNMB were high-occupancy areas for all turtles. Across all years, approximately 0.02\% $\left(0.01 \mathrm{~km}^{2}\right)$ of the $25 \%$ UD extended south of PNMB. For 2004 approximately $14 \%$ (4.7 of 33.4 total $\mathrm{km}^{2}$ ) extended south of PNMB, for $2005100 \%\left(10.7 \mathrm{~km}^{2}\right)$ was contained within PNMB and for 2007 approximately $34 \%$ (44.4 of $128.5 \mathrm{~km}^{2}$ ) extended north of PNMB (Fig. 3). The highest use habitats within PNMB occurred within a $6 \mathrm{n}$ mile $(\sim 11.1 \mathrm{~km})$ range from the shore. Turtles occupied habitats across the entire $12 \mathrm{n}$ miles $(\sim 22.2 \mathrm{~km})$ longitudinal extent of the PNMB, throughout the Gulf of Papagayo around the Santa Elena Peninsula and across the entirety of Santa Rosa National Marine Park (37117 ha land, 78000 ha marine area) (Fig. 2).

Tag-derived SST experienced by the turtles within the core $25 \%$ UD polygon for all years averaged $27.6^{\circ} \mathrm{C}$ $\left(\mathrm{SD}=0.82^{\circ} \mathrm{C}\right.$, range $=25.9$ to $29.2^{\circ} \mathrm{C}$ ), which was similar to that within the noncore 25 to $95 \%$ UD (mean = $27.5^{\circ} \mathrm{C}, \mathrm{SD}=1.6^{\circ} \mathrm{C}$, range $=20.1$ to $31.1^{\circ} \mathrm{C}$ ). Satellitederived SST data (Fig. 3) across the entire internesting MCP averaged $27.2^{\circ} \mathrm{C}$ during January of all years (SD $=0.5^{\circ} \mathrm{C}$, range $=24.2$ to $29.6^{\circ} \mathrm{C}$ ), $27.0^{\circ} \mathrm{C}$ during February $\left(\mathrm{SD}=0.4^{\circ} \mathrm{C}\right.$, range $=23.1$ to $30.8^{\circ} \mathrm{C}$ ) and $27.5^{\circ} \mathrm{C}$ during March $\left(\mathrm{SD}=0.4^{\circ} \mathrm{C}\right.$, range $=22.7$ to $30.5^{\circ} \mathrm{C}$ ).

Turtles that remained within the internesting habitats for more than $1 \mathrm{~d}(\mathrm{n}=45)$ tended to disperse in close proximity to the coast, within a mean distance of $10 \mathrm{~km}$ from the shore, and to occupy continental shelf habitats, although offshore movements beyond the edge of the shelf (in waters exceeding $1500 \mathrm{~m}$ depth) did occur during each tracking season. Turtles nesting at PNMB had easy access to deep waters due to the narrow continental shelf off the Nicoya Peninsula, which quickly sloped to depths in excess of $6000 \mathrm{~m}$ within the Middle American Trench (Fig. 1). Bottom depths across the entire internesting MCP ranged to $5034 \mathrm{~m}($ mean $=1327.8, \mathrm{SD}=1545.3 \mathrm{~m})$.

\section{Vertical movements}

After filtering, a total of 20848 internesting dives were obtained via Argos. The total number of dives observed per turtle (including 35 SMRU SRDL-tagged turtles and excluding turtle no. 56272 for which no vertical internesting behavior was recorded) across all tracking years ranged from 21 to 1918 dives (mean = 595.7, $\mathrm{SD}=463.1$ dives), with mean depth of $23.4 \mathrm{~m}$ $(\mathrm{SD}=6.5$, range $=13.4$ to $42.4 \mathrm{~m})$ and mean maximum depth of $108.2(\mathrm{SD}=53.3 \mathrm{~m}$, range $=39$ to $314 \mathrm{~m})$ (Table 3). Mean dive durations across all tracking years ranged from 6.1 to 20.3 min with a mean dive duration of $11.6 \mathrm{~min}(\mathrm{SD}=3.7 \mathrm{~min})$, and a mean maximum dive duration of $27.2 \mathrm{~min}(\mathrm{SD}=7.3$, range $=17.5$ to $51.2 \mathrm{~min}$ ). Turtles spent approximately $65.4 \%$ (SD = $16.1 \%$ ) of their time diving (depth $\geq 10 \mathrm{~m}$ ) during the internesting period (Table 3). Turtle dive depths and dive durations were significantly deeper within both the $25 \%$ UD and 25 to $95 \%$ UD (25\% UD: KruskalWallis $H=166.0, \mathrm{p}<0.01 ; 25$ to $95 \%$ UD: Kruskal-Wallis $H=131.0, \mathrm{p}<0.01$ ) and longer (25\% UD: KruskalWallis $H=166.8, \mathrm{p}<0.01 ; 25$ to $95 \%$ UD: Kruskal-Wallis $H=328.7, \mathrm{p}<0.01$ ) during 2007 than during 2004 and 2005 (Fig. 5).

During the day, turtles dove, on average, approximately $5 \mathrm{~m}$ deeper and reached mean maximum depths approximately $41 \%$ greater than at night (mean $=107.7$ and $76.6 \mathrm{~m}$ during day and night, respectively; $t$-test: $t=-3.2$ and $-2.9, \mathrm{df}=68, \mathrm{p}<0.01$ and $\mathrm{p}<0.01$, respectively). Turtle mean dive durations did not differ significantly between day and night $(t=$ -0.2 , df $=68, \mathrm{p}=0.83$ ).

Tag-derived SST (depth $=1 \mathrm{~m}$ ) did not vary significantly among years (Kruskal-Wallis $H=0.2, \mathrm{p}=0.90$ ) within the core area $25 \%$ UD polygons. However, the temperatures at mean dive depths within the 2004 and $200525 \%$ UD polygons were significantly cooler than those within the $200725 \%$ UD polygon (Kruskal-Wallis $H=22.6, \mathrm{p}<0.01$ ) (Fig. 5).

The temperature-depth use pattern for 2007 was different than for 2004 and 2005, showing a bimodal trend that was not apparent in the previous 2 tracking years (Fig. 6). Our analysis revealed that internesting turtles spent most of their time in shallow depths in 2007 (depth $<15 \mathrm{~m}$ ) within warmer temperatures ranging from 28 to $29^{\circ} \mathrm{C}$. It also showed nearly as high usage within the 27 to $28^{\circ} \mathrm{C}$ range at depths to approximately $35 \mathrm{~m}$. The highest use region extended over a temperature range of approximately 15 to $30^{\circ} \mathrm{C}$ to a depth of approximately $80 \mathrm{~m}$. The depths and temperature ranges occupied during 2007 were greater than those for the previous 2 tracking years (Fig. 6).

\section{DISCUSSION}

Recent studies have examined the influence of environmental factors on leatherback turtle foraging and migration behavior in the eastern Pacific at the ocean basin scale (Saba et al. 2008, Shillinger et al. 2008, Reina et al. 2009). Currently, little information exists regarding the influence of oceanographic conditions within their internesting habitats. Short-term behavioral studies of internesting leatherback turtles using time-depth recorders (Reina et al. 2005, Wallace et al. 2005), heart rate monitors (Southwood et al. 1999) and 
Table 3. Dermochelys coriacea. Vertical movement data for leatherback turtles satellite tagged at Playa Grande, Costa Rica, during $2004(\mathrm{n}=27), 2005(\mathrm{n}=8)$ and $2007(\mathrm{n}=11)$. Mean values for each year are in bold text. PTT ID: tag identification no.; na: data not available

\begin{tabular}{|c|c|c|c|c|c|c|c|c|}
\hline \multirow{2}{*}{ PTT ID } & \multirow{2}{*}{$\begin{array}{c}\text { No. of } \\
\text { dives }\end{array}$} & \multicolumn{3}{|c|}{$\ldots$ Dive depth $(\mathrm{m})$} & \multirow[b]{2}{*}{ Max. } & \multirow{2}{*}{$\begin{array}{c}\text { Dive duration (min) } \\
\text { Mean }\end{array}$} & \multirow[b]{2}{*}{$\mathrm{SD}$} & \multirow{2}{*}{$\begin{array}{l}\text { Dive frequency } \\
\quad(\% \text { time })\end{array}$} \\
\hline & & Max. & Mean & SD & & & & \\
\hline \multicolumn{9}{|l|}{2004} \\
\hline 37595 & 797 & 124.00 & 25.27 & 19.19 & 37.8 & 12.58 & 8.57 & 78.98 \\
\hline 37596 & 779 & 39.00 & 13.38 & 6.71 & 39 & 13.38 & 7.49 & 78.65 \\
\hline 41687 & na & na & na & na & na & na & na & na \\
\hline 41688 & na & na & na & na & na & na & na & na \\
\hline 41689 & na & na & na & na & na & na & na & na \\
\hline 41690 & na & na & na & na & na & na & na & na \\
\hline 41691 & na & na & na & na & na & na & na & na \\
\hline 41692 & na & na & na & na & na & na & na & na \\
\hline 41693 & na & na & na & na & na & na & na & na \\
\hline 41694 & na & na & na & na & na & na & na & na \\
\hline 41695 & na & na & na & na & na & na & na & na \\
\hline 41696 & na & na & na & na & na & na & na & na \\
\hline 41697 & 873 & 120.00 & 19.40 & 15.02 & 17.5 & 7.28 & 4.27 & 70.11 \\
\hline 41698 & 430 & 68.00 & 20.06 & 12.60 & 25.5 & 9.42 & 5.33 & 73.92 \\
\hline 41699 & 349 & 104.00 & 17.92 & 12.74 & 26.17 & 8.55 & 5.33 & 70.91 \\
\hline 41700 & 733 & 100.00 & 15.25 & 11.88 & 20.17 & 6.07 & 3.81 & 74.01 \\
\hline 41701 & 175 & 55.00 & 21.46 & 12.77 & 24.17 & 11.64 & 5.56 & 78.53 \\
\hline 41702 & 270 & 128.00 & 23.83 & 19.69 & 21.5 & 9.52 & 5.68 & 66.1 \\
\hline 41703 & 1314 & 84.00 & 15.60 & 10.13 & 21.5 & 8.54 & 10.13 & 74.8 \\
\hline 41704 & 856 & 88.00 & 22.84 & 14.82 & 33.83 & 9.64 & 6.84 & 78.24 \\
\hline 41705 & 233 & 104.00 & 24.31 & 14.54 & 30.83 & 15.93 & 8.23 & 80.67 \\
\hline 41706 & 474 & 88.00 & 22.07 & 15.67 & 24.83 & 9.3 & 5.74 & 72.97 \\
\hline 41707 & 79 & 68.00 & 29.12 & 14.39 & 24.17 & 15.31 & 6.48 & 70.25 \\
\hline 41708 & 470 & 112.00 & 20.11 & 14.81 & 26.83 & 9.45 & 5.94 & 79.06 \\
\hline 41709 & 206 & 100.00 & 24.94 & 18.18 & 22.17 & 9.8 & 5.83 & 80.2 \\
\hline 41710 & 612 & 80.00 & 20.30 & 12.75 & 18.17 & 20.3 & 12.75 & 66.78 \\
\hline 41711 & 1918 & 72.00 & 16.48 & 9.38 & 22.83 & 8.67 & 4.19 & 72.33 \\
\hline Mean & 622 & 90.24 & 20.73 & 13.84 & 25.71 & 10.90 & 6.60 & 74.50 \\
\hline $\mathrm{SD}$ & 464 & 24.80 & 4.16 & & 6.29 & 3.59 & & 4.66 \\
\hline \multicolumn{9}{|l|}{2005} \\
\hline 56268 & 486 & 142.00 & 20.39 & 17.42 & 29.5 & 10.21 & 6.56 & 80.72 \\
\hline 56272 & na & na & na & na & na & na & na & na \\
\hline 56274 & 130 & 72.00 & 28.41 & 13.22 & 30.17 & 14.84 & 7.01 & 61.88 \\
\hline 56276 & 629 & 68.00 & 15.75 & 9.87 & 17.50 & 8.41 & 3.69 & 55.97 \\
\hline 56279 & 349 & 88.00 & 19.04 & 15.86 & 20.17 & 8.91 & 5.04 & 68.42 \\
\hline 56280 & 1102 & 100.00 & 14.76 & 11.44 & 25.50 & 7.50 & 5.62 & 51.71 \\
\hline 56282 & 368 & 55.00 & 18.43 & 9.96 & 19.50 & 8.87 & 4.63 & 64.69 \\
\hline 56283 & 603 & 120.00 & 18.16 & 14.96 & 32.50 & 11.13 & 7.29 & 79.18 \\
\hline Mean & 524 & 92.14 & 19.28 & 13.25 & 24.98 & 9.98 & 5.69 & 66.08 \\
\hline $\mathrm{SD}$ & 306.32 & 30.85 & 4.46 & & 5.96 & 2.45 & & 10.95 \\
\hline \multicolumn{9}{|l|}{2007} \\
\hline 72474 & 338 & 80.00 & 27.41 & 17.09 & 26.17 & 10.97 & 6.29 & 51.51 \\
\hline 72475 & 21 & 96.00 & 31.97 & 22.69 & 17.5 & 9.38 & 5.06 & 4.93 \\
\hline 72476 & 749 & 112.00 & 27.43 & 18.63 & 32.5 & 13.37 & 7.08 & 62.79 \\
\hline 72477 & 370 & 116.00 & 33.04 & 23.11 & 36.5 & 17.47 & 8.70 & 57.63 \\
\hline 72478 & 1622 & 100.00 & 23.78 & 18.69 & 27.5 & 10.19 & 5.75 & 72.19 \\
\hline 72479 & 504 & 100.00 & 28.13 & 16.20 & 29.5 & 13.98 & 6.70 & 61.05 \\
\hline 72480 & 483 & 246.00 & 32.28 & 27.99 & 51.17 & 19.15 & 12.98 & 54.03 \\
\hline 72481 & 1785 & 120.00 & 21.61 & 15.57 & 28.17 & 9.69 & 5.98 & 65.61 \\
\hline 72482 & 131 & 158.00 & 42.38 & 27.70 & 31.5 & 17.54 & 7.96 & 30.81 \\
\hline 72483 & 364 & 166.00 & 28.57 & 24.17 & 24.83 & 10.43 & 6.26 & 32.89 \\
\hline 72485 & 246 & 314.00 & 33.65 & 26.79 & 35.17 & 18.25 & 7.56 & 67.03 \\
\hline Mean & 601.18 & 146.18 & 30.02 & 21.69 & 30.96 & 13.67 & 7.30 & 50.95 \\
\hline $\mathrm{SD}$ & 578.93 & 72.52 & 5.59 & & 8.50 & 3.80 & & 20.18 \\
\hline
\end{tabular}




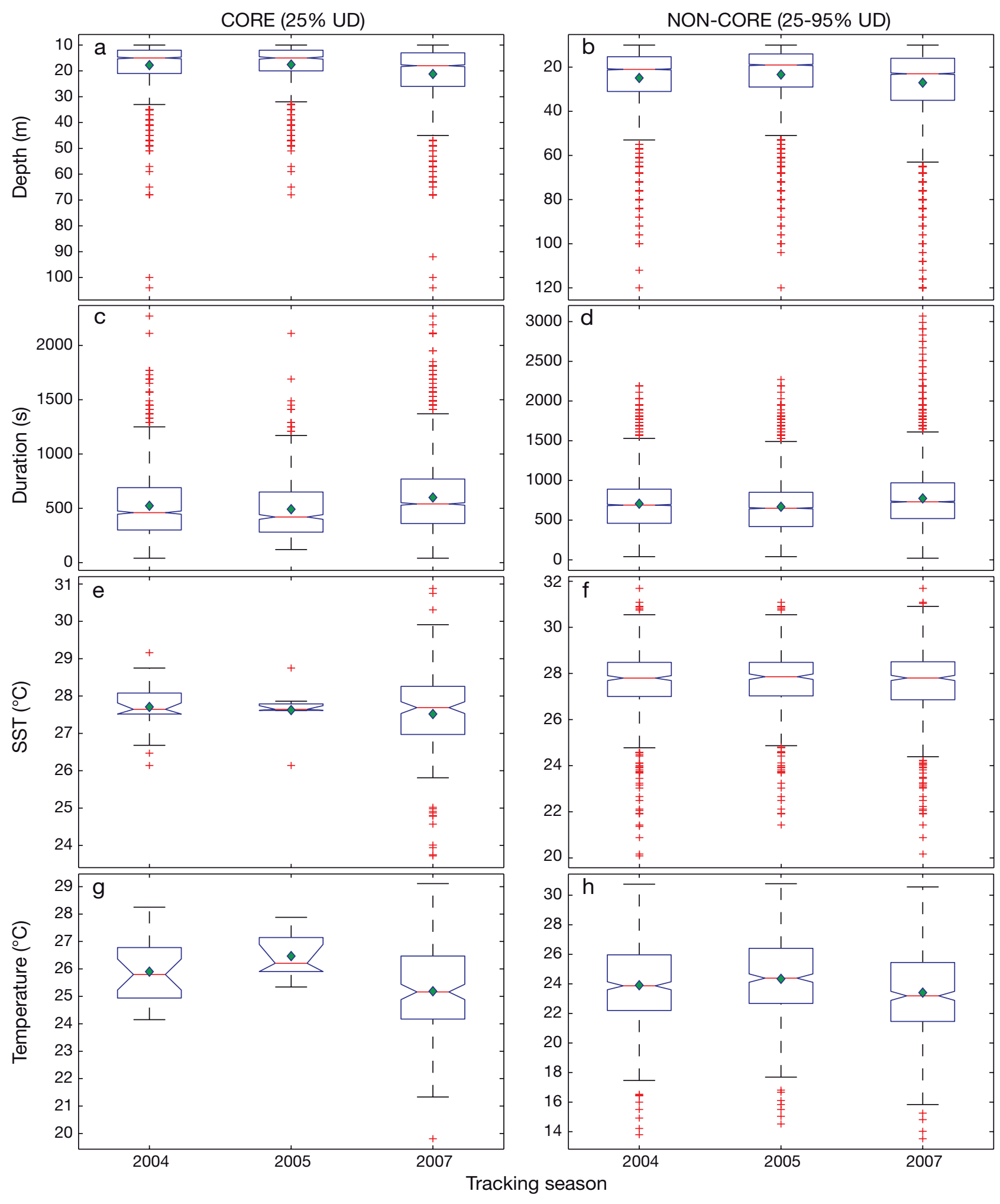

Fig. 5. Dermochelys coriacea. Environmental influences on turtle behavior and temperatures $\left({ }^{\circ} \mathrm{C}\right)$ experienced by turtles at surface (SST) and at mean dive depths during 2004, 2005 and 2007 within internesting $25 \%$ utilization distribution (UD, core) and 25 to $95 \%$ UD (noncore) regions. Box plots for (a) median dive depth within $25 \%$ UD, (b) median dive depth within $2 \%$ to $95 \%$ UD, (c) median dive duration within $25 \% \mathrm{UD}$, (d) median dive duration within 25 to $95 \%$ UD, (e) median tag-derived SST ( ${ }^{\circ} \mathrm{C}$ ) within $25 \%$ UD, (f) median tag-derived SST $\left({ }^{\circ} \mathrm{C}\right)$ within 25 to $95 \%$ UD, $(\mathrm{g})$ median temperature $\left({ }^{\circ} \mathrm{C}\right)$ at mean dive depth within $25 \%$ UD and (h) median temperature $\left({ }^{\circ} \mathrm{C}\right)$ at mean dive depth within 25 to $95 \%$ UD. Boxes show the first and third quartiles; red lines show the median; whiskers encompass all non-outlier data points; red cross-hatches denote outliers, and green diamonds the means 

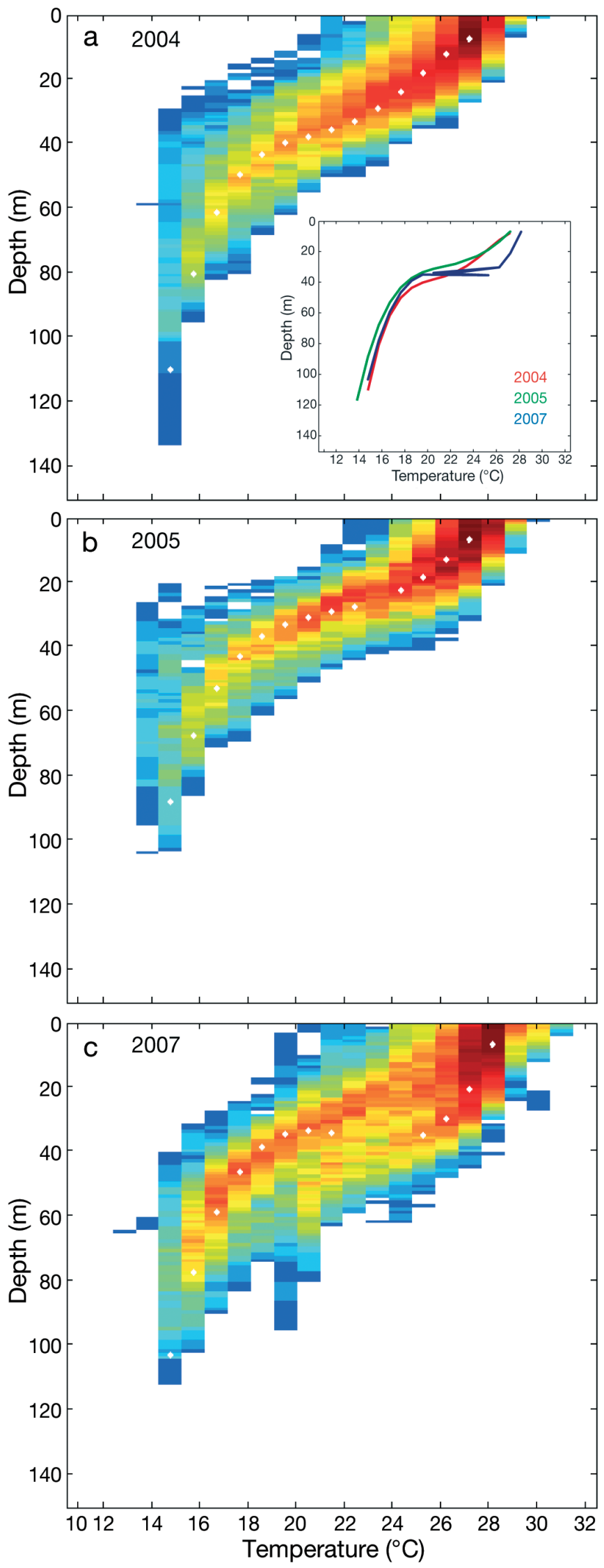

body temperature probes (Southwood et al. 2005) have provided valuable insights into the vertical behaviors, physiology, foraging ecology and metabolic rates of turtles nesting at Playa Grande. Our study complements these efforts by providing an integrated horizontal and vertical context of habitat use and examining these movements in relation to the interannual variability in oceanographic features. The capacity to combine satellite tagging data with oceanographic data provided an unparalleled opportunity to define the critical habitat.

The leatherback turtle nesting season at Playa Grande coincides with a series of predictable environmental transitions in the eastern Pacific Ocean, many of which are driven by topographically influenced wind forcing from the American continents (Kessler 2006). Leatherback turtles nesting at Playa Grande arrive during September to October from putative foraging grounds in the South Pacific (Shillinger et al. 2008). This internesting region is flanked from the west by the cool nutrientrich waters of the CRD, characterized by a productive region of elevated thermocline centered at $9^{\circ} \mathrm{N}, 90^{\circ} \mathrm{W}$. To the north, seasonal winter winds that form the Papagayo jet push through Central American mountain passes and move out over the Gulf of Papagayo, thereby enriching the waters of the Nicoya Peninsula. From the south, the deep (subthermocline) northwestward flowing CRCC, bathes the coast of Costa Rica in a strong jet of warm water that flows ( $\left.20 \mathrm{~cm} \mathrm{~s}^{-1}\right)$ from the eastern edge of the CRD and continues into the Gulf of Tehuantepec (GOT) off the coast of Mexico (Kessler 2006). The Playa Grande internesting region is subject to interannual fluctuations in SST, sea surface height (SSH) and chlorophyll a ( $\mathrm{chl}$ a) concentrations associated with the waxing

Fig. 6. Dermochelys coriacea. Frequency of turtle occupancy, expressed as ln (utilization frequency), within a temperature and depth $(T-Z)$ space defined as $T=1{ }^{\circ} \mathrm{C}$ by $Z=1 \mathrm{~m}$ boxes for (a) 2004, (b)

0.52005 and (c) 2007. In (utilization frequency) ranges from $<1$ (blue) through the spectral range to $>5$ (dark red). The white diamonds refer to a 3rd-order fit (inset in panel a) through the peak temperature utilization points within each $1 \mathrm{~m}$ depth interval 
(El Niño) or waning (La Niña) of the North Equatorial Countercurrent (NECC) in the Central Pacific. The impact of these phenomena on the availability of prey resources for foraging leatherback turtles in other regions of the eastern Pacific has recently been linked to timing of leatherback remigration intervals and changes in their reproductive ecology in the eastern Pacific (Saba et al. 2007, Reina et al. 2009). Although the precise mechanism is unclear, we suggest that interannual changes in oceanographic conditions, even at small scales (internesting region), can also influence the behavior and distribution of internesting leatherback turtles.

During the 3 internesting seasons at Playa Grande, we observed strong transitions in SST and NPP (Figs. 3 $\& 4$ ) that coincided with the peak of nesting (between December and January) and with the end of internesting (between February and March). Although mean monthly SST for January, February and March within the internesting $\mathrm{MCP}$ did not vary considerably for each of the tracking years $\left(26.5\right.$ to $\left.28.0^{\circ} \mathrm{C}\right)$, during all years the range of SST available to the turtles (within this same region) increased from January to February as wind-forced upwelling (note the coastal upwelling cool SST signal in Fig. 3d-1) drove colder water into the northern part of the internesting region. During 2004 and 2005, the range of satellite-observed SST available to the turtles peaked during February and declined in March. During 2007, a warming trend from the south driven by a strong CRCC was countered by cooling from the north and a strong CRD signal (Fig. 31), which dramatically increased the SST range from February through March within the MCP (Fig. 3f,i,l).

We also examined tag-derived SST within core and noncore internesting habitats to obtain a direct measure of turtle temperature preferences. Our findings demonstrated no significant differences in turtle SST preference among tracking years (Fig. 5), and revealed that internesting turtles during all years occupied a mean SST range of approximately 27.5 to $27.7^{\circ} \mathrm{C}$ within both the internesting core and noncore regions. However, during 2007, the turtles dispersed more widely, ranged farther north and swam at higher maximum speeds than during the other $2 \mathrm{yr}$. Additionally, turtles targeted a mean temperature range of 25.2 to $26.5^{\circ} \mathrm{C}$ while diving across tracking seasons, and when the range of available temperatures was greatest in 2007, they seemed to adjust their dive behavior to target cooler waters at slightly deeper depths during the warmer period of 2007 (Figs. $5 \& 6$ ). These results corroborate findings of Wallace et al. (2005) that leatherback turtles might behaviorally thermoregulate by selecting particular ranges of water temperatures available to them in internesting habitats. Thus, the occupation of specific SSTs appears to be critical for the biology of the leatherback turtle and the internesting period, because temperatures may in fact be optimal for physiological performance (e.g. egg production) in the warm waters associated with the internesting period (Wallace et al. 2005, Schofield et al. 2009). Selection of the temporal and spatial habitat associated with breeding may be driven by the seasonality and be related to a critical thermal window that opens at the time of year when breeding occurs.

We attribute the distinct vertical and horizontal behaviors of the turtles in this year to the effects of the warm CRCC (Fig. 3). The GOP emerged as a high-use area during 2007, where turtles could access cooler upwelled waters and seek refuge from the warm waters and strong CRCC in the lee of the Santa Elena Peninsula (Fig. 3). Turtle swim speeds may have been affected by the increased strength of the CRCC during this year. A positive relationship between increased turtle swim speeds versus increased current strengths was observed within the same population of turtles during their postnesting migrations as they traversed high energy equatorial zonal currents (Shillinger et al. 2008). The 2004 and 2005 tracking years were oceanographically more similar to each other than they were to 2007. The coldest year in the tracking dataset, 2005, was characterized by strong Papagayo upwelling and the weakest CRCC in the tracking dataset. During this period turtles remained close to the nesting beach and exhibited the lowest mean swim speeds and shallowest mean dive behavior (although not significantly so), which may have been a direct result of the cooler water. However, it is difficult to discern the turtles' thermal limits without further investigation of their internal body temperatures during diving.

Synthesizing the relationships between variation in vertical and horizontal movements and environmental drivers, we suggest that the observed turtle movements may have reflected a compensatory thermoregulatory response. Thus, turtles move horizontally or vertically to exploit preferred water temperatures, thereby maintaining a physiologically optimal thermal range (Paladino et al. 1990, Wallace et al. 2005).

Turtle movements might also have been related to foraging activity, with turtles dispersing into productive habitats within the GOP to find prey (Myers \& Hays 2006, Fossette et al. 2008b). Their nocturnal (shallower) dive behavior also implied that turtles may have been following vertically migrating prey (Eckert et al. 1989). The hypothesis of leatherback turtles foraging during the nesting season has been supported by active swimming behaviors, diving patterns and beak movements (Fossette et al. 2008b). Potential prey items are known to occur in the vicinity of nesting 
beaches, although direct observations of feeding have not yet been made (Reina et al. 2005, Fossette et al. 2009).

Turtle vertical movements were constrained by bathymetry, with shallower dives occurring in shallower waters immediately adjacent to the nesting beach and increasing in depth (to $314 \mathrm{~m}$, Table 3) as turtles moved westward towards the edge of the continental shelf. The shallow dive behavior within shelf waters has been reported previously for Playa Grande leatherback turtles (Southwood et al. 1999, Wallace et al. 2005) and observed within other populations of internesting leatherback turtles, including in French Guiana (Fossette et al. 2007, Georges et al. 2007), Malaysia (Eckert et al. 1996) and Gabon (Georges et al. 2007). Although offshore excursions were relatively infrequent, turtles nesting at PNMB had access to deep waters (exceeding $1500 \mathrm{~m}$ ) offshore in the nearby Middle America Trench (Fig. 1).

The results in this study only reflect the behavior of female turtles, since tagging occurred on the nesting beach. It is much more difficult logistically to tag males as they do not come on land. However, there are increasing efforts to tag male turtles (James et al. 2005, Schofield et al. 2009). As temperatures increase as a result of climate change, male offspring will become rarer and they will play an increasingly important role (Hawkes et al. 2007).

While the use of harnesses for tag attachment on leatherback turtles has been the standard technique since its development more than 20 yr ago (Eckert \& Eckert 1986), studies now indicate that there may be a hydrodynamic effect of the harness on the turtle's swimming and diving capabilities (Fossette et al. 2008a, Byrne et al. 2009). There have also been observed effects of tagging and handling on the turtles (Sherrill-Mix \& James 2008), suggesting the need for less invasive and less time-consuming attachment methods. A recent new development has been the use of direct attachment devices, for which preliminary assessments have been made (Doyle et al. 2008, Fossette et al. 2008a, Byrne et al. 2009). However, it is clear that the effects of any tagging technique should be carefully considered and weighed against the potential conservation benefits to make it justifiable. Particularly when involving endangered species, the fitness costs of tagging should be minimized as much as possible to ensure we are not contributing to their decline (Sherrill-Mix \& James 2008).

Our study revealed that the current delineation of the marine sector of PNMB and related conservation measures (e.g. fishing inside the park is prohibited) for internesting leatherback turtles from the Playa Grande population are well-targeted and effective, but these efforts should be augmented because turtles fre- quently move well beyond the boundaries of PNMB (Fig. 2; Shillinger et. al 2008), and because the fisheries that might have important impacts on leatherback turtles typically occur outside of the park boundaries. Park rangers perform patrols to enforce the prohibition on fishing activities within PNMB, but these activities are predominantly small-scale hand-line operations that probably would not have deleterious effects on the turtles. However, trawl vessels are also spotted close to or within PNMB boundaries and could interact with leatherback and other sea turtles within the park. In addition to trawls, other fishing gears (e.g. longlines and coastal gill nets) are known to affect sea turtles in Costa Rica's exclusive economic zone (Arauz 2001, Arauz et al. 1998), and potential interactions between these gear types and internesting leatherback turtles from PNMB merit attention.

The entire internesting habitat region (internesting MCP, Fig. 2) over the 3 yr tracking period was encompassed within an area of approximately $33542 \mathrm{~km}^{2}$, ranging as far south as the tip of the Nicoya Peninsula and north into waters offshore from southern Nicaragua (Fig. 2). High Argos location errors could lead to artifacts in the size of the home range (e.g. see Bradshaw et al. 2007), but as Argos location classes were broadly similar across individuals and different years our inferences about temporal changes in home ranges are likely to be robust. Recently developed high resolution GPS tracking might lead to more refined estimates of home range (Schofield et al. 2007). Although there was significant interannual variation in turtle dispersal and habitat use, the internesting core region (25\% UD) consistently occurred within or around PNMB during every tracking year (Fig. 2). Given the high degree of nesting-site fidelity displayed by the Playa Grande turtles, it was expected that waters in the immediate vicinity of the nesting beach would comprise core habitats.

Our findings validated the importance of PNMB as critical habitat necessary for leatherback turtle conservation and substantiated the efficacy of current governmental and nongovernmental collaborative efforts to address leatherback turtle conservation within PNMB, especially within the marine sector. For example, we observed no indication of possible mortality of turtles during the internesting periods (i.e. all turtles performed postnesting migrations, Shillinger et al. 2008), which might suggest that bycatch effects in the internesting areas that leatherback turtles occupied across multiple years were minimal. Thus, at least within the marine sector of $\mathrm{PNMB}$, no-take regulations appear to be effective in reducing leatherback turtle bycatch. However, because internesting leatherback turtles also occupy areas outside of the current PNMB boundaries, expanded protection of this species in 
marine areas outside of the park, particularly during the breeding season in October to March (Fig. 2), should be considered. We propose that the ongoing conservation efforts at PNMB be integrated with other marine protected areas within the identified leatherback turtle internesting region along the Nicoya Peninsula, including Santa Rosa National Park, and Caletas and Camaronal refuges (Fig. 3). In addition, we recommend programs to raise awareness and engage local communities along the Guanacaste coast about the existence of the no-take PNMB and about the seasonal presence of leatherback turtles to bolster any official management actions to protect the species in Costa Rican waters.

Our findings also demonstrated that interannual environmental variation influences the distribution and behavior of internesting leatherback turtles. The transboundary movements of these turtles into Nicaraguan waters and their wide dispersal along the Nicoya Peninsula require the development of cooperative regional and international strategies for their management and conservation. Moreover, the near-shore, continental shelf-based movements of internesting leatherback turtles probably expose the turtles to anthropogenic threats, such as coastal fisheries and possible pollution from development zones. Our study has improved the understanding of environmental influences upon leatherback turtle behavior and distribution, particularly during the internesting period when reproductively active turtles are concentrated, and will be very useful to conservation initiatives designed to protect this population.

Acknowledgements. This research was sponsored by the Tagging of Pacific Pelagics program of the Census of Marine Life and supported by the Office of Naval Research of the United States Navy, the UNESCO World Heritage Program (via the United Nations Foundation and Global Conservation Fund of Conservation International), the Alfred P. Sloan Foundation, the Gordon and Betty Moore Foundation, the Packard Foundation, Earthwatch Institute and the National Aeronautics and Space Administration (NASA) through a grant provided by the Applied Sciences Program in the Earth Science Division. The research was performed in accordance with the Stanford University Protocol for the Care and Use of Laboratory Animals (APLAC no. 13848). The authors thank The Leatherback Trust, Earthwatch Institute and the Betz Chair of Environmental Science at Drexel University for their assistance with this project. The altimeter products were produced by Ssalto/Duacs and distributed by Aviso, with support from CNES, France. The authors thank the Ocean Biology Processing Group at the NASA/Goddard Space Flight Center for the production and distribution of the SeaWiFS ocean color data. These activities are sponsored by NASA's Mission to Planet Earth Program. The Smith and Sandwell digital bathymetry was obtained from the Institute of Geophysics and Planetary Physics at the Scripps Institution of Oceanography. We thank J. Thompson, J. Wible, S. Eckert, D. Palacios, L. DeWitt, M. Fedak, P. Lovell, J. Ganong, D. Kohrs, V. Saba and P. Santidrián-Tomillo for technical assistance. The Costa Rican Ministry of Natural Resources and the Environment provided research permits. We also thank G. Goldring, the Goldring Marine Biology Station and the staff and volunteers at PNMB for support at Playa Grande.

\section{LITERATURE CITED}

Arauz R (2001) Impact of high seas longline fishery operations on sea turtle populations in the Exclusive Economic Zone (EEZ) of Costa Rica - a second look. In: Coyne MC, Clark RD (eds) Proc 21st Annu Symp Sea Turtle Biology and Conservation, Philadelphia, PA. NOAA Tech Memo NMFS-SEFSC-528

Arauz R, Vargas R, Naranjo I, Gamboa C (1998). Analysis of the incidental capture and mortality of sea turtles in the shrimp fleet of Pacific Costa Rica. In: Epperly SP, Braun J (eds) Proc 17th Annual Sea Turtle Symp, Miami, FL. NOAA Tech Memo NMFS-SEFSC-415, Part I:1-5

Bailey H, Shillinger G, Palacios D, Bograd S, Spotila J, Paladino F, Block B (2008) Identifying and comparing phases of movement by leatherback turtles using state-space models. J Exp Mar Biol Ecol 356:128-135

> Bradshaw CJA, Sims DW, Hays GC (2007) Measurement error causes scale-dependent threshold erosion of biological signals in animal movement data. Ecol Appl 17: 628-638

Byrne R, Fish J, Doyle TK, Houghton JDR (2009) Tracking leatherback turtles (Dermochelys coriacea) during consecutive inter-nesting intervals: further support for direct transmitter attachment. J Exp Mar Biol Ecol 377: $68-75$

> Congdon JD, Dunham AE, Van Lobel Sels RC (1993) Delayed sexual maturity and demographics of Blandings turtles (Emydoidea blandingii): implications for conservation and management of long-lived organisms. Conserv Biol 7: 826-833

> Doyle TK, Houghton JDR, O'Súilleabháin PF, Hobson VJ, Marnell F, Davenport J, Hays GC (2008) Leatherback turtles satellite-tagged in European waters. Endang Species Res 4:23-31

- Eckert SA (2002) Swim speed and movement patterns of gravid leatherback sea turtles (Dermochelys coriacea) at St Croix, US Virgin Islands. J Exp Biol 205:3689-3697

Eckert SA, Eckert KL (1986) Harnessing leatherbacks. Mar Turtle Newsl 37:1-3

- Eckert SA, Eckert KL, Ponganis P, Kooyman GL (1989) Diving and foraging behavior by leatherback sea turtles (Dermochelys coriacea). Can J Zool 67:2834-2840

Eckert SA, Liew HC, Eckert KL, Chan EH (1996) Shallow water diving by leatherback turtles in the South China Sea. Chelonian Conserv Biol 2:237-243

> Fedak M, Lovell P, McConnell B, Hunter C (2002) Overcoming the constraints of long range radio telemetry from animals: getting more useful data from smaller packages. Integr Comp Biol 42:3-10

Fossette S, Ferraroli S, Tanaka H, Ropert-Coudert Y and others (2007) Dispersal and dive patterns in gravid leatherback turtles during the nesting season in French Guiana. Mar Ecol Prog Ser 338:233-247

Fossette S, Corbel H, Gaspar P, Le Maho Y, Georges JY (2008a) An alternative technique for the long-term satellite tracking of leatherback turtles. Endang Species Res 4: 33-41

> Fossette S, Gaspar P, Handrich Y, Le Maho Y, Georges JY (2008b) Dive and beak movement patterns in leatherback 
turtles Dermochelys coriacea during internesting intervals in French Guiana. J Anim Ecol 77:236-246

Fossette S, Girard C, Bastian T, Calmettes B and others (2009) Thermal and trophic habitats of the leatherback turtle during the nesting season in French Guiana. J Exp Mar Biol Ecol 378:8-14

Georges JY, Fossette S, Billes A, Ferraroli S and others (2007) Meta-analysis of movements in Atlantic leatherback turtles during the nesting season: conservation implications. Mar Ecol Prog Ser 338:225-232

Hawkes LA, Broderick AC, Godfrey MH, Godley BJ (2007) Investigating the potential impacts of climate change on a marine turtle population. Glob Change Biol 13:923-932

> Hays GC, Houghton JDR, Myers AE (2004) Pan-Atlantic leatherback turtle movements. Nature 429:522

$>$ Heppell SS, Crowder LB, Crouse DT (1996) Models to evaluate headstarting as a management tool for long-lived turtles. Ecol Appl 6:556-565

Hyrenbach KD, Keiper C, Allen SG, Ainley DG, Anderson DJ (2006) Use of marine sanctuaries by far-ranging predators: commuting flights to the California Current System by breeding Hawaiian albatross. Fish Oceanogr 15:95-103

> James MC, Eckert SA, Myers RA (2005) Migratory and reproductive movements of male leatherback turtles (Dermochelys coriacea). Mar Biol 147:845-853

Jonsen ID, Myers RA, Fleming JM (2003) Meta-analysis of animal movement using state-space models. Ecology 84: 3055-3063

Kessler WS (2006) The circulation of the eastern tropical Pacific: a review. Prog Oceanogr 69:181-217

Morreale SJ, Standora EA, Spotila JR, Paladino FV (1996) Migration corridor for sea turtles. Nature 384:319-320

Myers AE, Hays GC (2006) Do leatherback turtles Dermochelys coriacea forage during the breeding season? A combination of data-logging devices provide new insights. Mar Ecol Prog Ser 322:259-267

> Nordmoe ED, Sieg AE, Sotherland PR, Spotila JR, Paladino FV, Reina RD (2004) Nest site fidelity of leatherback turtles at Playa Grande, Costa Rica. Anim Behav 68: 387-394

Palacios DM, Bograd SJ (2005) A census of Tehauntepec and Papagayo eddies in the northeastern tropical Pacific. Geophys Res Lett 32:L23606 doi:23610.21029/22005GL024324

Paladino FV, O'Connor MP, Spotila JR (1990) Metabolism of leatherback turtles, gigantothermy, and thermoregulation of dinosaurs. Nature 344:858-860

Reina RD, Mayor PA, Spotila JR, Piedra R, Paladino FV (2002) Nesting ecology of the leatherback turtle, Dermochelys coriacea, at Parque Nacional Marino Las Baulas, Costa Rica: 1988-1989 to 1999-2000. Copeia 2002:653-664

Reina RD, Abernathy KJ, Marshall GJ, Spotila JR (2005) Respiratory frequency, dive behaviour and social interactions of leatherback turtles, Dermochelys coriacea during the inter-nesting interval. J Exp Mar Biol Ecol 316:1-16

Reina RD, Spotila JR, Paladino FV, Dunham AE (2009) Changed reproductive schedule of eastern Pacific leatherback turtles Dermochelys coriacea following the 1997-98 El Niño to La Niña transition. Endang Species Res 7:155-161

Saba VS, Santidrián-Tomillo P, Reina RD, Spotila JR, Musick JA, Evans DA, Paladino FV (2007) The effect of the El Niño Southern Oscillation on the reproductive frequency of eastern Pacific leatherback turtles. J Appl Ecol 44:395-404
Saba VS, Shillinger GL, Swithenbank AM, Block BA, Spotila JR, Musick JA, Paladino FV (2008) An oceanographic context for the foraging ecology of eastern Pacific leatherback turtles: consequences of ENSO. Deep-Sea Res I 55:646-660

- Santidrián-Tomillo P, Vélez E, Reina RD, Piedra R, Paladino FV, Spotila JR (2007) Reassessment of the leatherback turtle (Dermochelys coriacea) nesting population at Parque Nacional Marino Las Baulas, Costa Rica: effects of conservation efforts. Chelonian Conserv Biol 6:54-62

Santidrián-Tomillo P, Saba VS, Piedra R, Paladino FV, Spotila JR (2008) Effects of illegal harvest of eggs on the population decline of leatherback turtles in Las Baulas Marine National Park, Costa Rica. Conserv Biol 22: 1216-1224

Schofield G, Bishop CM, MacLean G, Brown P and others (2007) Novel GPS tracking of sea turtles as a tool for conservation management. J Exp Mar Biol Ecol 347:58-68

Schofield G, Lilley MKS, Bishop CM, Brown P and others (2009) Conservation hotspots: implications of intense spatial area use by breeding male and female loggerheads at the Mediterranean's largest rookery. Endang Species Res 10:191-202

Seaman DE, Powell RA (1996) An evaluation of the accuracy of kernel density estimators for home range analysis. Ecology 77:2075-2085

Sherrill-Mix SA, James MC (2008) Evaluating potential tagging effects on leatherback sea turtles. Endang Species Res 4:187-193

Shillinger GL, Palacios DM, Bailey H, Bograd SJ and others (2008) Persistent leatherback turtle migrations present opportunities for conservation. PLoS Biol 6:e171

Smith WHF, Sandwell DT (1997) Global seafloor topography from satellite altimetry and ship depth soundings. Science 277:1957-1962

> Southwood AL, Andrews RD, Lutcavage ME, Paladino FV, West NH, George RH, Jones DR (1999) Heart rates and diving behavior of leatherback sea turtles in the eastern Pacific Ocean. J Exp Biol 202:1115-1125

Southwood AL, Andrews RD, Paladino FV, Jones DR (2005) Effects of diving and swimming behavior on body temperatures of Pacific leatherback turtles. Physiol Biochem Zool 78:285-297

Spotila JR, Reina RD, Steyermark AC, Plotkin PT, Paladino FV (2000) Pacific leatherback turtles face extinction. Nature 405:529-530

Stearns SC (1992) The evolution of life histories. Oxford University Press, Oxford

Steyermark A, Williams K, Spotila JR, Paladino FV and others (1996) Nesting leatherback turtles at Las Baulas National Park, Costa Rica. Chelonian Conserv Biol 2:173-183

> Wallace BP, Saba VS (2009) Environmental and anthropogenic impacts on intra-specific variation in leatherback turtles: opportunities for targeted research and conservation. Endang Species Res 7:11-21

- Wallace BP, Williams CL, Paladino FV, Morreale SJ, Lindstrom RT, Spotila JR (2005) Bioenergetics and diving activity of internesting leatherback turtles Dermochelys coriacea at Parque Nacional Marino Las Baulas, Costa Rica. J Exp Biol 208:3873-3884

> Worton BJ (1989) Kernel methods for estimating the utilization distribution in home-range studies. Ecology 70: $164-168$ 